\title{
Meiofaunal communities and nematode diversity characterizing the Secca delle Fumose shallow vent area (Gulf of Naples, Italy)
}

\author{
Elisa Baldrighi ${ }^{\text {Corresp. } 1,2}{ }^{2}$, Daniela Zeppilli ${ }^{2}$, Luca Appolloni ${ }^{3,4}{ }^{\text {, Luigia Donnarumma }}{ }^{3,4}$, Elena Chianese ${ }^{3}$, Giovanni \\ Fulvio Russo $^{4,5}$, Roberto Sandulli ${ }^{3,4}$ \\ ${ }^{1}$ Istituto per le Risorse Biologiche e le Biotecnologie Marine (IRBIM), Consiglio Nazionale delle Ricerche (CNR), Lesina, Italy, Italy \\ ${ }^{2}$ Laboratoire Environnement Profond, Institut Français de Recherche pour l'Exploitation de la MER (IFREMER), Plouzané, France, France \\ 3 Department of Science and Technology (DiST), Parthenope University of Naples, Naples, Italy, Italy \\ 4 Consorzio Nazionale Interuniversitario per le Scienze del Mare (CoNISMa), Rome, Italy, Italy \\ 5 Department of Science and Technology (DiST),, Parthenope University of Naples, Naples, Italy, Italy \\ Corresponding Author: Elisa Baldrighi \\ Email address: elisa.baldrighi@irbim.cnr.it
}

Hydrothermal venting is rather prevalent in many marine areas around the world, and marine shallow vents are relatively abundant in the Mediterranean Sea, especially around Italy. However, investigations focusing on the characterization of meiofaunal organisms inhabiting shallow vent sediments are still scant compared to that on macrofauna. In the present study, we investigated the meiobenthic assemblages and nematode diversity inhabiting the Secca delle Fumose (SdF), a shallow water vent area located in the Gulf of Naples (Italy). In this area, characterized by a rapid change in the environmental conditions on a relative small spatial scale (i.e., one hundred of meters), we selected four sampling sites: one diffusive emission site $(H)$; one geyser site $(G)$ and two inactive sites (CN, CS). Total meiofauna abundance did not vary significantly between active and inactive sites and between surface and deeper sediment layers due to a high interreplicate variability, suggesting a pronounced spatial-scale patchiness in distribution of meiofauna. Nematofauna at site H presented the typical features of deep-sea vents with low structural and functional diversity, high biomass and dominance of few genera (i.e. Oncholaimus; Daptonema) while from site $\mathrm{G}$ we reported diversity values comparable to that of the inactive sites. We hypothesized that site $G$ presented a condition of 'intermediate disturbance' that could maintain a high nematode diversity. Environmental features such as sediment temperature, $\mathrm{pH}$, total organic carbon and interstitial waters ions were found to be key factors influencing patterns of meiofauna and nematofauna assemblages at SdF. Even though the general theory is that nematodes inhabiting shallow vent areas include a subset of species that live in background sediments, this was not the case for SdF vent area. Due to a marked change in nematode composition between all 
sites and to the presence of many exclusive species, every single investigated site was characterized by a distinct nematofauna reflecting the high spatial heterogeneity of SdF. 
2 Meiofaunal communities and nematode diversity characterizing the Secca delle Fumose 3 shallow vent area (Gulf of Naples, Italy)

5 Elisa Baldrighi ${ }^{1,2}$, Daniela Zeppilli ${ }^{2}$, Luca Appolloni ${ }^{3,4}$, Luigia Donnarumma ${ }^{3,4}$, Elena Chianese ${ }^{3}$,

6 Giovanni Fulvio Russo ${ }^{3,4}$ and Roberto Sandulli ${ }^{3,4}$

$8{ }^{1}$ Istituto per le Risorse Biologiche e le Biotecnologie Marine (IRBIM), Consiglio Nazionale delle

9 Ricerche (CNR), Lesina, Italy;

${ }^{2}$ Institut Français de Recherche pour l'Exploitation de la MER (IFREMER), Laboratoire Environnement Profond, Plouzané, France;

$12{ }^{3}$ Department of Science and Technology (DiST), Parthenope University of Naples, Naples, Italy

$13{ }^{4}$ Consorzio Nazionale Interuniversitario per le Scienze del Mare (CoNISMa), Rome, Italy

\section{Corresponding author:}

15 Elisa Baldrighi ${ }^{1,2}$

16 Via Pola, 4, 71010, Lesina, Italy

17 Email address: elisa.baldrighi@,irbim.cnr.it

18

Keywords: Secca delle Fumose, Gulf of Naples, shallow vent, meiofauna, nematode diversity

\section{Abstract}

Hydrothermal venting is rather prevalent in many marine areas around the world, and marine shallow vents are relatively abundant in the Mediterranean Sea, especially around Italy. However, investigations focusing on the characterization of meiofaunal organisms inhabiting shallow vent sediments are still scant compared to that on macrofauna. In the present study, we investigated the meiobenthic assemblages and nematode diversity inhabiting the Secca delle Fumose (SdF), a shallow water vent area located in the Gulf of Naples (Italy). In this area, characterized by a rapid change in the environmental conditions on a relative small spatial scale (i.e., one hundred of meters), we selected four sampling sites: one diffusive emission site (H); one geyser site $(\mathrm{G})$ and two inactive sites $(\mathrm{CN}, \mathrm{CS})$. Total meiofauna abundance did not vary significantly between active and inactive sites and between surface and deeper sediment layers 
33 due to a high inter-replicate variability, suggesting a pronounced spatial-scale patchiness in 34 distribution of meiofauna. Nematofauna at site $\mathrm{H}$ presented the typical features of deep-sea vents 35 with low structural and functional diversity, high biomass and dominance of few genera (i.e. 36 Oncholaimus; Daptonema) while from site $\mathrm{G}$ we reported diversity values comparable to that of 37 the inactive sites. We hypothesized that site $\mathrm{G}$ presented a condition of intermediate 38 disturbance' that could maintain a high nematode diversity. Environmental features such as 39 sediment temperature, $\mathrm{pH}$, total organic carbon and interstitial waters ions were found to be key 40 factors influencing patterns of meiofauna and nematofauna assemblages at SdF. Even though the general theory is that nematodes inhabiting shallow vent areas include a subset of species that live in background sediments, this was not the case for SdF vent area. Due to a marked change in nematode composition between all sites and to the presence of many exclusive species, every 44 single investigated site was characterized by a distinct nematofauna reflecting the high spatial heterogeneity of SdF.

habitats both in the deep-sea and in shallow coastal habitat (e.g., Melwani \& Kim, 2008). Shallow vents are often associated with active plate boundaries, and consequently volcanic or seismic activities are related to sites of littoral and sub-littoral thermal venting (Tarasov et al., 1999). The environmental conditions in shallow-water vents strongly differ from the surrounding seafloor in terms of both increased temperature and enrichment in reduced chemical compounds such as sulphide, methane, manganese, iron and arsenic (Prol-Ledesma et al., 2004). Fluids formation commonly take place from relatively deep sources (1-2 km depth) and these natural fluid emissions may be able to alter sea-water geochemistry (Di Bella et al., 2016). Pore-water temperatures tend to significantly increase compared to ambient conditions (Pichler et al., 1999). Furthermore, numerous studies have reported vent fluids with low salinity and acidic pH (i.e., Melwani \& Kim, 2008 and literature therein). The high temperature, coupled with gas release and variable chemical conditions due to hydrothermal activity may create biologically stressful environments. 
64 Differently from deep-sea hydrothermal vents based exclusively on chemosynthetic primary 65 production, shallow-water vents are characterized by the presence of light that coupled with that

66 of geothermal fluids, promotes both photo- and chemosynthetic primary production (Sorokin et al., 1998; Tarasov et al., 2005). Most ecological studies investigating shallow water hydrothermal vents were focused on microbial communities, which are strongly influenced by the hydrothermal activity both within the water column and on the seabed (Judd \& Hovland, 2007; Di Bella et al., 2016). Shallow-water vents can differ in terms of faunal density, diversity and dominance (i.e. metazoan organisms) from the surroundings and from each other, depending on the degree and effects of the venting activity (Jones, 1993; Panieri et al., 2005; Panieri, 2006a; Melwani \& Kim, 2008; Wildish et al., 2008).

At deep-sea hydrothermal vents, an increase in number of meiobenthic animals coupled with a reduction in the diversity compared to non-vent areas has been reported (Copley et al., 2007 and literature therein; Zeppilli et al., 2018). Nematodes and copepods are the most abundant taxa and studies conducted along the East Pacific Rise reported that usually copepods are the initial dominant meiofaunal colonizers of 'new' vent mussel beds, with a general increase in the percentage ratio of nematodes to copepods over time (Flint et al., 2006; Copley et al., 2007). Deep-water hydrothermal vents in general do not show high nematode densities or biomass and also their diversity is much lower than that in surrounding deep-sea sediments (Vanreusel et al., 2010). Despite their ubiquitous distribution in tectonically active coastal zones, shallow-water vents have been less explored than deep-sea vents in terms of biodiversity and adaptations to extreme conditions (Colangelo et al., 2001; Tarasov et al., 2005). Investigations focusing on the characterization of meiofaunal organisms inhabiting shallow vent sediments are still scant compared to that on macrobenthic communities and they span different geographical areas, from Mediterranean Aegean Sea (Dando et al., 1995; Fitzsimons et al., 1997; Thiermann et al., 1994; Thiermann et al., 1997), Tyrrhenian Sea (Colangelo et al., 2001; Panieri et al., 2005; Panieri, 2006a; Di Bella et al., 2016), Adriatic Sea (Panieri et al., 2006b), Strait of Sicily (Sandulli et al., 2015) to New Zealand (Kamenev et al., 1993), Papua New Guinea (Tarasov et al., 1999), Indonesian archipelago (Zeppilli \& Danovaro, 2009), the shallow sub-polar region of the Mid Atlantic Ridge (Fricke et al., 1989), Azores (Cardigos et al., 2005), and including the comprehensive reviews by Tarasov et al. (2005) and Zeppilli et al. (2018). 
94 Shallow vents are characterized by non-endemic meiofauna that show higher diversity and 95 abundance than in background sediments (Tarasov et al. 2005). While deep-sea vents are 96 inhabited by unique nematode assemblages, at least at species level (Vanreusel et al. 1997;

97 Thiermann et al., 1997), shallow-water vent nematodes include a subset of species that can both 98 live in the background sediments and cope with extreme conditions (Zeppilli \& Danovaro, 99 2009). Also for copepods, shallow vent assemblages seem to be the result of colonization from 100 adjacent areas (Colangelo et al., 2001; Zeppilli \& Danovaro, 2009).

101 Hydrothermal venting in shallow water is a common phenomenon and marine shallow vents are 102 abundant in the Mediterranean, in particular in the Tyrrhenian Sea (Hall-Spencer et al., 2008).

103 The present work represents the first investigation on the meiobenthic communities inhabiting 104 Secca delle Fumose $(\mathrm{SdF})$ shallow water vent area located in the Underwater Archaeological 105 Park of Baia (Gulf of Naples, Italy).

106 The peculiarity of this active area is the rapid change in the extreme environmental conditions,

107 from the diffusive vent site and geyser site with hot temperatures to inactive sites (see below), at 108 a relatively small spatial scale i.e., one hundred of meters. SdF can be considered an example of 109 how hydrothermal flux can vary at small scale in the vent habitat (Flint et al., 2006), creating a 110 gradient in the environmental conditions, from extreme to ambient conditions.

111 The present paper reports a first insight into the meiofaunal and nematode communities of SdF 112 shallow vent area and describes the distribution and diversity of meiobenthic organisms in 113 relation to seawater chemistry and sediment characteristics. Due to changes in stress regime and 114 environmental conditions, we expect different meiofauna and nematofauna assemblages 115 inhabiting the distinct sampling sites.

\section{Material \& Methods}

\section{Site description}

120 The study area of SdF is located in the north-west side of the Gulf of Naples (Baia Underwater 121 Park MPA, Tyrrhenian Sea, Italy; Fig.1). The coastline consists mainly of beaches and tuff cliffs.

122 Volcanic activity is still evident both for bradyseism process, which led to the immersion of 123 many Roman structures, and for sulfurous emanations. The interaction between natural processes 124 and human activities produced a natural environment characterized by an extreme habitats' 
125 variety (Fig. 1). Photophilous algae habitat (AP) is observed on docks, while strong 126 interdigitation between photophilous populations, which are setting up on the parts most exposed 127 to light, and sciaphilous populations (C) setting in the cavities (AP-C), is present on Roman 128 artifacts. Superficial muddy sands in sheltered water habitat (SVMC) dominates soft bottoms. 129 Near the submerged structures SVMC habitats are enriched with fragments come from the 130 disintegration of the artifacts and from carbonate exoskeletons of benthic organisms; here are 131 recorded species belonging to the coarse sands and fine gravels under the influence of bottom 132 currents habitat (SGCF) (as previously described in Appolloni et al., 2018). SdF is a submarine 133 relief consisting of a network of ancient Roman pillars, among which thermal vents releasing hot

134 gas-rich hydrothermal fluids occur (D'Auria et al., 2011). This area has been previously 135 investigated from a geological point of view (Todesco, 2009; D’Auria et al., 2011 and literature 136 therein), and, very recently, with the only macrobenthic and environmental published study so 137 far known (Donnarumma et al., 2019). All details regarding the sampling site are reported in 138 Donnarumma et al. (2019).

\section{Sampling methods and samples processing}

142 For our study, we selected four sampling sites, at 9-14 m water depth, over a total of $\sim 7500 \mathrm{~m}^{2}$ 143 sampling area: one diffusive emission site (H, "White") characterized by the presence of white 144 microbial mats covering the soft bottom; one geyser site (G, "Yellow") at $65 \mathrm{~m}$ distance from the $145 \mathrm{H}$ site, with surrounding rocky substrate covered by yellow sulphur deposits and with hot water 146 emissions reaching $80^{\circ} \mathrm{C}$ at the sediment surface; two inactive sites (CN and CS) located at a 147 distance of $100 \mathrm{~m}$ from the active sites H and G (Fig.1). Environmental data were collected as 148 previously describe in Donnarumma et al. (2019). Interstitial waters to assess ions and heavy 149 metals concentrations and sediment samples (three random replicates) were collected at the four 150 selected sites. Cylindrical corers (internal diameter $5.5 \mathrm{~cm}$ ) were used to collect sediment for 151 grain size, total organic carbon (TOC) and meiofaunal communities by scuba diving. The 152 meiofauna sediment cores were sliced into four layers $0-1,1-3,3-5$ and 5-10 cm and fixed in 153 buffered $4 \%$ formalin/seawater.

\section{Environmental variables}


156 All details on the environmental variable analyses considered in the present study i.e., interstitial 157 waters ion $\left(\mathrm{Na}^{+}, \mathrm{Cl}^{-}, \mathrm{K}^{+}, \mathrm{Mg}^{2+}, \mathrm{Ca}^{2+}, \mathrm{NO}_{3}{ }^{-}, \mathrm{SO}_{4}{ }^{2-}\right.$ and $\left.\mathrm{S}^{2-}\right)$ and heavy metal $(\mathrm{Zn}, \mathrm{Pb}, \mathrm{Cd}$ and $\mathrm{Cu})$ 158 concentrations, sediment grain size (as percentage of gravel, sand and mud) and total organic 159 carbon (TOC) are reported in Donnarumma et al. (2019).

\section{Meiobenthos and nematode analyses}

162 Sediment samples were sieved through a $1000 \mu \mathrm{m}$ mesh, and a $30 \mu \mathrm{m}$ mesh was used to retain 163 the smallest organisms. The fraction remaining on the latter sieve was re-suspended and 164 centrifuged with Ludox HS40 according to Heip et al. (1985). All meiobenthic animals were 165 counted and classified per taxon under a stereomicroscope. From each sample, approximately 166 100-120 nematodes were picked out, transferred to anhydrous glycerin following the formalin167 ethanol-glycerin protocol (De Grisse, 1969), and mounted on paraffin ring glass slides for 168 microscopic identification. Nematodes were identified at genus level and diversified in putative morphotypes as $\mathrm{sp} 1, \mathrm{sp} 2$, etc. according to the main original species descriptions (Platt \& Warwick, 1983, 1988; Warwick, Platt \& Somerfield, 1998; Tchesunov \& Schmidt-Rhaesa, 2014) and pictorial keys available on the Nemys website (Bezzerra et al., 2018). Nematode biomass was calculated from the biovolume using the Andrassy (1956) formula (V $=\mathrm{L} \times \mathrm{W}^{2} \times 0.063 \mathrm{x}$ $10^{-5}$, in which $\mathrm{L}$ is the body length and $\mathrm{W}$ is the body width). Species richness (SR) was calculated as the total number of species collected at each site; the expected number of species for a theoretical sample of 51 specimens, ES(51), was selected and Pielou's (1975) evenness (J') was estimated.

177 Furthermore, nematode genera were categorized in four feeding guilds based on their buccal

178 cavity morphology as described by Wieser (1953). Feeding guilds included "selective deposit 179 feeders" (Group 1A, small buccal cavity without teeth), "non-selective deposit feeders" (Group 180 1B, large buccal cavity without teeth), "epistrate feeders" (Group 2A, small buccal cavity with 181 teeth) and "predators/scavengers" (Group 2B, lager buccal cavity with teeth). The index of 182 trophic diversity (ITD) as ITD $=\mathrm{g}_{1} 2+\mathrm{g}_{2} 2+\mathrm{g}_{3} 2 \ldots+\mathrm{g}_{\mathrm{n}} 2$, where $\mathrm{g}$ is the relative contribution of 183 each trophic group to the total number of individuals and $\mathrm{n}$ is the number of trophic groups 184 (Gambi et al., 2003). For $\mathrm{n}=4$, ITD ranges from 0.25 (highest trophic diversity, i.e. the 4 trophic 185 guilds account for $25 \%$ each) to 1.0 (lowest diversity i.e., one trophic guild accounts for $100 \%$ of 186 nematode density). To identify the life strategy of nematodes, the maturity index (MI) was 
187 calculated according to the weighted mean of the individual genus scores: $\mathrm{MI}=\Sigma v(\mathrm{i}) f(\mathrm{i})$, where

$188 v$ is the $\mathrm{c}-\mathrm{p}$ value (colonizers-persisters) of genus $\mathrm{i}$ as given in the appendix of Bongers et al.

189 (1991) and $f(\mathrm{i})$ is the frequency of that genus.

190

\section{Data analysis}

192 Uni- and multivariate analyses were carried out in order to assess differences in several 193 descriptors of meiofauna (i.e. abundance, number of taxa, assemblage composition) and 194 nematode assemblage composition (i.e. abundance, biomass, SR, ES(51), J', ITD and MI) 195 between sites and layers. Faunal data were $\log _{(\mathrm{X}+1)}$ transformed and analyzed using tests based 196 on Bray-Curtis similarity matrices (multivariate analyses) and Euclidean similarity matrices 197 (univariate analyses).

198 The sampling design included two fixed and orthogonal factors: site (4 levels: G, H, CN and CS) 199 and layer (4 levels: 0-1, 1-3, 3-5 and 5-10 cm). The distance-based permutation analysis of 200 variance (PERMANOVA; Anderson et al., 2008) in either univariate (separately for each 201 meiofauna and nematode diversity index) or multivariate data (for both meiofaunal and 202 nematode assemblages) was used for testing for differences in taxonomic composition between 203 sites and layers. Pair-wise tests were carried out to verify the significance of the differences 204 among sites and layers if any were observed in the main test.

205 Afterwards, the relative contribution of each nematode species to the average dissimilarities 206 between sites and layers was calculated using SIMPER test (using 70\% as cutoff) to determine 207 the contribution of each species (Clarke \& Warwick, 2001). The diversity in nematode 208 community composition is expressed as percentages of dissimilarity (Gray, 2000). A CLUSTER 209 analysis (group average) was carried out and a similarity profile test (SIMPROF) permutational 210 routine was applied to test for the significance of genuine clustering on meiofaunal assemblage 211 composition and nematode species composition characterizing the sampling sites.

212 Multivariate multiple regression analyses (DistLM forward, Anderson et al., 2008) with a 213 forward selection of the independent variables and 4999 permutation of residuals were 214 performed to test the influence of abiotic variables (sediment and interstitial water variables) on 215 meiofaunal abundance, richness of taxa and taxonomic composition, nematode biomass, species 216 composition and diversity indices, nematode trophic diversity and nematode life strategies. All 
217 the analyses were carried out by means of the software PRIMER v6.0 + (Clarke \& Gorley, 218 2006).

219

220

221

\section{Results}

222

223

\section{Environmental variables}

224 Environmental characteristics of sampling sites at SdF are reported and described in detail in 225 Donnarumma et al. (2019). The H site, the diffusive emission site in the southern sector, was characterized by the highest sediment temperature $\left(37.53 \pm 2.28^{\circ} \mathrm{C}\right)$ and by the lowest $\mathrm{pH}$ value of (7.56 \pm 0.05$)$. At this site, sediment was mainly composed by the sandy fraction enriched in TOC content and the soft bottom presented a coverage of white microbial mat. At G site (geyser, northern sector), located at $65 \mathrm{~m}$ from the $\mathrm{H}$ site, the sediment temperature reported was $29.1 \pm 2.81^{\circ} \mathrm{C}$. This site was the only one characterized by the presence of sulphur ion $\mathrm{S}^{2-}$ into the interstitial waters. $\mathrm{CN}$ and $\mathrm{CS}$ constituted the inactive sites at a distance of $100 \mathrm{~m}$ from $\mathrm{G}$ and $\mathrm{H}$ sites. The sediment temperature $\left(21.8^{\circ} \mathrm{C}\right)$ and $\mathrm{pH}(8.1)$ values were comparable to the surrounding environment. All sampling sites were clearly differed due to many environmental features that changed over a relatively small spatial scale $(100 \mathrm{~m})$ and indicating a marked spatial heterogeneity (Donnarumma et al., 2019).

\section{Meiofauna abundance, taxonomic composition and distribution}

238 The mean meiofaunal abundances and abundance of each taxon at each sampling sites and along

239 the sediment layers are reported in Table S1. The total meiofaunal abundance ranged from $2401142 \pm 713.8$ ind. $/ 10 \mathrm{~cm}^{2}$ (mean \pm standard error, hereafter) at $\mathrm{CN}$ site to $2023 \pm 1270.2 \mathrm{ind} . / 10 \mathrm{~cm}^{2}$ 241 at $\mathrm{G}$ site (Fig. 2). At all sampling sites, with the only exception for the inactive site $\mathrm{CN}$, an 242 increase of meiofaunal abundance from the surface sediment $(0-1 \mathrm{~cm})$ to the deeper sediment 243 layer (5-10 cm; Fig. 3) was recorded. Nevertheless, PERMANOVA analysis did not detect any 244 significant effect of factors 'site' and 'layer' on total meiofauna abundance (Table 1). The total 245 nematode abundances followed the total meiofaunal trends (Fig. 2 and 3). Significant lower 246 values in the total nematode abundance were reported at site $\mathrm{H}$ compared to sites $\mathrm{G}$ and CS

247 (Table 1). The abundance of nematodes increased significantly from the top 1 centimeter to the 
248 deepest layer at sites H and CS (; Fig. 3 and Table 1). A total of 27 higher taxa, including 249 Foraminifera and Ciliata, were identified from the sediments of SdF (Table S1). The total 250 number of meiobenthic taxa ranged from $11 \pm 1$ at site $H$ to $20 \pm 1$ at site G. PERMANOVA 251 analysis indicated that 'site' and the combined effect of SxL were the factors explaining 252 meiofaunal diversity variability in the number of major taxa (Table 1). In detail, the pair-wise 253 test showed that site $\mathrm{H}$ was characterized by a significant lower meiofaunal diversity compared 254 to all other sites (Table 1). Meiofaunal taxonomic composition changed significantly between 255 sites (Table 1), the pair-wise test detected major differences between site $\mathrm{H}$ vs. all the other sites 256 and the CLUSTER analysis clearly highlighted this separation (Figure 4).

257 With the only exception of site H, Nematoda were the most represented taxon (36-57\%), 258 followed by Copepoda Harpacticoida and their nauplii (21-30\%), Foraminifera (12-13\%) and 259 Polychaeta (4-8\%) (Table S1, Fig. 5). Other taxa, such as Tardigrada, Ciliata, Ostracoda, 260 Gastropoda and Halacarida typically occurred in lower numbers (2-5\%) or only occasionally 261 (e.g., Kinorhyncha, Gastrotricha, Amphipoda, Tanaidacea, Cumacea, Isopoda). At site H, 262 harpacticoid copepods and their nauplii were the most represented groups (41\%) followed by 263 Ciliata (29.5\%) and Nematoda (24\%). SIMPER analysis on meiofaunal taxonomic composition 264 characterizing the four sampling sites reported a dissimilarity percentage between site $\mathrm{H}$ and all 265 the other sites ranging from 27 to $31 \%$. The dissimilarity was mainly due to a different 266 contribution of taxa, in term of abundances, at the different sampling sites and secondly to the 267 absence of Tardigrada and Gastrotricha at the diffusive site $(\mathrm{H})$. Ostracoda, Polychaeta, 268 Gasteropoda and Halacarida, occurred frequently (2-8\%) at sites G, CN and CS; other taxa, such 269 as Ciliata and Copepoda were found in high abundances at site H (Table S1, Fig. 5). Meiofauna 270 taxonomic composition did not change significantly along the vertical sediment profile. Overall, 271 nematode abundances increased with depth layer, Copepoda (with their nauplii), on the opposite, 272 decreased deepening into the sediment. These patterns characterized all sampling sites (Table S1, 273 Fig. 6).

274

275 Nematode biomass, structural and functional diversity

276 A complete list of nematodes identified and total biomass values at each sampling site and at 277 different sediment depth layers are reported in Table S2. Total biomass values ranged from $27847.1 \pm 8.7$ to $149.3 \pm 72.6 \mu \mathrm{g} \mathrm{C}$ at sites $\mathrm{G}$ and $\mathrm{H}$, respectively. PERMANOVA analysis indicated 
279 that nematode biomass changed significantly between sites and along the vertical profile (Table 280 1). In details, the pair-wise test reported significant higher biomass values at site $\mathrm{H}$ compared to 281 all the other sites and significant lower biomass values characterizing site $\mathrm{G}$ compared to the 282 inactive sites. Moreover, nematode biomass significantly increased going deeper into the 283 sediment and showing higher values at $3-5 \mathrm{~cm}$ and $5-10 \mathrm{~cm}$ layers compared to the top 3 284 centimeters at all sites except for CS (Table 1).

285 Nematode diversity indices $\left(\mathrm{SR} ; \mathrm{ES}_{(51)} ; \mathrm{J}\right)$, and functional diversity indices (ITD; MI) are 286 reported in Table 2. Since we did not detect any significant differences in nematode composition 287 with sediment depth layer (see below), we assessed for differences in diversity and functional 288 indices only between sites (Table 1). Site $\mathrm{H}$ showed significant lower values in nematode 289 diversity (SR; $\left.\mathrm{ES}_{(51)}\right)$ and equitability (J') compared to all the other sites; while the inactive site 290 CS was characterized by significant lower values for J' index compared to CN and G. Overall, a 291 total of 33 families and 2 subfamilies; 156 genera and 165 species (i.e. morphotypes) were 292 identified.

293 The PERMANOVA results showed significant effect of the factor 'site' on nematode community 294 composition (Table 1). The SIMPER analysis revealed a dissimilarity of $87-94 \%$ between site $\mathrm{H}$ 295 and all other sites, of $55-57 \%$ between site $\mathrm{G}$ and inactive sites and of $50 \%$ between sites $\mathrm{CN}$ and 296 CS (see also CLUSTER analysis, Fig. 7).

297 Among all identified families, the most diversified in term of number of genera were 298 Desmodoridae (25 genera), Chromadoridae (21 genera), Cyatholaimidae (14 genera), 299 Comesomatidae (11 genera) and Xyalidae (10 genera). Four families, represented only by one 300 genus, were encountered just in one of the investigated sites: Ceramonematidae (site G), 301 Siphonolaimidae (site H), Rhabdolaimidae and Rhadinematidae (site CS) (Table S2). A total of 30258 exclusive species were identified, all of them represented by few individuals (between 0.1 $3031.9 \%$ of the total abundances). The diffusive site $\mathrm{H}$ was characterized by the dominance of two 304 nematode species Oncholaimus sp1 and Daptonema sp1 (less than 1\% in the other sites) and by 305 the presence of Elzalia sp1, Linhystera sp2 and Parastomonema sp1 as exclusive species. The 306 geyser site $\mathrm{G}$ was characterized by the presence of five abundant species Chromadorita sp1, 307 Desmodora sp1, Leptolaimus sp1, Microlaimus sp1and Paradesmodora sp1 and by 22 exclusive 308 species (Table S2). The inactive sites were characterized by the presence of 16 (at CN) and 17 (at 309 CS) unique species and by high abundances of Desmodora sp1, Paradesmodora sp1, Perspiria 
310 sp1 and Spirinia sp1 at CN site and by a slight dominance of Chromaspirina sp1 (33.4\%) and a

311 high abundance of Spirinia sp1 at CS (Table S2).

312 The trophic structure of nematode assemblages was dominated by predators/omnivores (2B;

$31378 \%)$ at site $\mathrm{H}$ and by epistrate feeders (2A) at sites $\mathrm{G}(72 \%)$ and site $\mathrm{CN}(71 \%)$; the inactive site

314 CS was characterized by the co-dominance of the groups $2 \mathrm{~A}(38 \%)$ and 2B (40\%) (Fig. 8).

315 Significant differences in the index of trophic diversity values between CS and all other sampling

316 sites (Table 1) was reported. Values of the maturity index were significantly higher at site $\mathrm{H}$ and

317 CS compared to the other sites (Table 1 and Table 2).

318

319 Relationship between meiofauna and environmental variables

320 The DistLM analysis was performed to assess the influence of environmental variables on faunal 321 assemblages (i.e., meiofauna abundance, taxonomic composition, number of major taxa, 322 nematode abundance and biomass, nematode composition and diversity, and nematode trophic 323 diversity). A combination of sediment (e.g., $\mathrm{pH}, \mathrm{T}^{\circ} \mathrm{C}$ and $\mathrm{TOC}$ content) and interstitial water 324 (e.g., $\mathrm{NO}_{3}{ }^{2-}, \mathrm{Na}^{+}, \mathrm{K}^{+}$and $\mathrm{S}^{2-}$ ) variables considered in our investigation might explain the 325 meiofauna and nematofauna variability in different percentage and depending on the meiofauna 326 and nematode descriptors considered (Table 3). The dbRDA graph (Fig. 9) on meiofauna 327 taxonomic composition showed a separation between sites due to changes in $\mathrm{T}^{\circ} \mathrm{C}$ (higher at $\mathrm{H}$ 328 site), $\mathrm{pH}$ (more acid at $\mathrm{H}$ site) and $\mathrm{NO}_{3}{ }^{2-}$ and $\mathrm{Cu}$ concentrations. All these variables could explain 329 the $73 \%$ of variability in meiofauna composition (Table 3). The dbRDA graph (Fig. 10) on 330 nematode composition showed that changes in nematode communities were significantly 331 correlated $(71 \%)$ to interstitial water features (Table 3 ) with a separation of the sampling sites 332 into three main groups: $\mathrm{H}, \mathrm{G}$ and the inactive sites $\mathrm{CN}-\mathrm{CS}$.

333

334 Discussion

335

336 Small-scale spatial environmental heterogeneity induced by vent emissions

337 Environmental conditions at hydrothermal vent systems markedly differ from background and 338 these differences include increase of temperature, decrease of $\mathrm{pH}$, and enrichment in reduced 339 compounds, gases and heavy metals (Tarasov et al., 2005). Shallow and deep vents are 340 characterized by high heterogeneity and can be defined as 'patchy habitats' (Gollner et al., 
341 2010). Due to hydrothermal activity, patchiness has often been detected in physical and chemical

342 variables at small spatial scales (Dando et al., 1995; Levin et al., 2003; Melwani \& Kim, 2008,

343 Gollner et al., 2010). Similarly, at the shallow vent area of SdF we detected a rapid change in the

344 environmental conditions with a consequent marked environmental heterogeneity on a relatively

345 small spatial scale (i.e., one hundred of meters).

346 SdF is characterized by three different habitats: 1) the diffusive emission site $(\mathrm{H})$ in which we

347 reported the highest temperature, acidic conditions as a result of $\mathrm{CO}_{2}$ gas bubbling (Di Napoli et

348 al., 2016) and the presence of a white microbial mat; 2) the solitary geyser site (G) which

349 differed from the other sites for the presence of sulphur ions in the interstitial waters and yellow

350 sulphurous deposits, medium-high temperature conditions but ambient $\mathrm{pH}$ values and 3) the

351 inactive sites ( $\mathrm{CN}$ and $\mathrm{CS}$ ) characterized by no extreme conditions ( $\mathrm{T}$ and $\mathrm{pH}$ values within the

352 natural range), the highest percentage of gravel fraction and the lowest TOC content compared to

353 the active sites.

354

355 Meiofauna distribution and taxonomic composition variability at vent conditions

356 In the deep-sea, vent emissions negatively impact fauna abundance (Kamenev et al., 1993;

357 Tarasov et al., 1999; 2005), while in shallow water the amount of food material derived from

358 both chemosynthesis and photosynthesis processes (Sorokin et al., 2003) promote the meiofauna

359 abundance that can reach higher values compared to the background sediments (Kamenev et al., 360 1993).

361 At SdF vent area active and inactive sites did not differ significantly in total meiofauna

362 abundance, contrarily to the drastic drop registered for the macrobenthic density at active sites

363 compared to the inactive sites at SdF (Donnarumma et al., 2019). Overall, total meiofauna

364 abundance reported in this study were higher than those at other shallow vent areas (Kamenev et

365 al., 1993; Thiermann et al., 1997; Tarasov et al., 1999; Colangelo et al., 2001, Zeppilli \&

366 Danovaro, 2009). The lack of significant differences between sites is possibly due to a

367 pronounced inter-replicates variability that reflects the irregular and patchy distribution of

368 meiofauna. We found the same small spatial-scale patchiness in the vertical distribution of

369 meiofauna, with no significant differences in total abundances moving deeper into the sediment

370 layers but only a trend in increasing abundance values from the surface to the deeper layers.

371 Meiofauna is known to be characterized by a patchy distribution and this is particularly evident 
372 at small spatial scale (i.e., microhabitats; Gallucci et al., 2009). At vents, the very small-scale

373 distribution is related to the spatial heterogeneity of biogeochemical vent processes that normally

374 occurs in these extreme environments (Tarasov et al., 2005; Di Bella et al., 2016). In this study,

375 the combination of vent small heterogeneity and meiofauna patchiness is particular evident.

376 Meiofauna distribution can vary more along the sediment vertical profile than along a horizontal

377 axe (Fonseca et al., 2010). Only few studies documented the vertical distribution of meiobenthic

378 organisms inhabiting shallow vent areas showing a decreasing trend with increasing sediment

379 depth (Ansari et al., 2001; El-Sehery et al., 2015; Di Bella et al., 2016). Sediment physical

380 disturbance is known to impact meiofaunal vertical distribution (Braeckman et al., 2011). In

381 some cases, nematodes can migrate from the surface disturbed layers into the less impacted

382 deeper layers (Leduc \& Pilditch 2013). At SdF the highest abundances were recorded at the

383 deeper layers. The bubble streams coupled with near-bottom currents and sediment rework by

384 larger fauna might possibly have a role in meiofauna sediment penetration by inducing a

385 migratory response to the deeper layers (Colangelo 2001; Steyaert et al., 2003).

386 Meiofauna diversity was higher at SdF than in the other shallow vent meiofauna studies (Fricke

387 et al., 1989; Kamenev et al., 1993; Dando et al., 1995; Tarasov et al., 1999; Colangelo et al.,

388 2001; Zeppili \& Danovaro, 2009). Nematodes represented a key taxon of meiobenthic

389 communities at shallow vents (Kamenev et al., 1993; Thiermann et al., 1997; Tarasov et al.,

390 2005). Similarly to results of Colangelo et al. (2001) and Zeppilli \& Danovaro (2009), we

391 reported a dominance of copepods at one of our four sites, site $\mathrm{H}$, which showed a different

392 assemblage structure in respect to the others. Previous authors (Coull, 1985; Colangelo et al.,

393 2001) explained this dominance invoking the alteration of sediment grain size and the preference

394 for coarser sediments by this taxon, coupled with the effect of intermediate disturbance created

395 by a moderate gas bubbling that seemed to promote copepod diversity (Colangelo et al., 2001).

396 At the diffusive emission site $(\mathrm{H})$, we did not detect any clear alteration of sediment grain size

397 but we can hypothesize a gas bubbling effect due to the presence of $\mathrm{CO}_{2}$ emissions. Moreover,

398 the presence of white microbial mat at site $\mathrm{H}$ could provide food for vent obligate copepods,

399 which have developed specific adaptation to feeding on bacterial mats (Heptner \& Ivanenko,

400 2002). High abundance of copepods characterized by a high species richness was reported also

401 from deep-sea vents (Gollner et al. 2010), confirming their ability to be well adapted to the

402 extreme vent conditions. Two other taxa, usually neglected in the meiobenthic studies because 
403 part of the unicellular organisms, constituted two abundant components of site $H$ vent 404 assemblage and they probably took advantage feeding on microbial mat: foraminifers and 405 ciliates. Bernhard et al. (2000) found that the microbial mats in the anoxic, sulphidic waters of 406 the Santa Barbara Basin supported abundant communities of foraminifera, flagellates and 407 ciliates. Benthic foraminifers represent an important environmental sensitive group and their 408 composition is strictly related to venting activity (Di Bella et al., 2016). Protists (e.g., ciliates) 409 play several roles in marine ecosystems and form a trophic link between prokaryotes and higher 410 trophic levels; they impact carbon and other nutrient cycles directly and indirectly through 411 grazing on organic matter and prokaryotic prey (Anderson et al., 2012).

412 The meiofaunal taxonomic composition usually varies between surface and subsurface sediment

413 layers: copepods and nauplii occupy the well oxygenated surface sediment layer (Grego et al., 414 2014), while nematodes become the dominant taxon at subsurface depths (Ingels et al., 2009;

415 Rosli et al., 2016). Meiobenthic organisms at SdF vent followed the same trends for nematodes 416 and copepods at all sites.

417

\section{Nematode community reflects Secca delle Fumose environmental heterogeneity}

419 At SdF shallow vent, nematode community composition and functional diversity varied from site to site reflecting the environmental heterogeneity of the sampling area. The same marked change in fauna composition was reported for the macrobenthic communities inhabiting SdF, with an absence of more sensitive species at the active sites (Donnarumma et al., 2019). The high variability in the nematode assemblages (i.e., percentage of dissimilarity between sites) and the presence of exclusive species characterizing each sampling site accounted for the differences in the biodiversity composition. This change in nematofauna was mainly due to a decrease of nematode genera/species at site $\mathrm{H}$ and to a change in the abundances and/or replacement of species among the other sites ( $\mathrm{G} v s . \mathrm{CN} v s . \mathrm{CS})$.

At the diffusive emission site $\mathrm{H}$, where we reported the most extreme conditions, nematode assemblage showed some typical traits of nematode assemblages inhabiting shallow

430 (Thiermann et al., 1994; Dando et al., 1995; Tarasov et al., 1999; Zeppilli \& Danovaro, 2009) 431 and deep-sea active vent sites (Tschesunov, 2015; Zeppilli et al., 2018): biomass values from 432 twofold to threefold higher compared to that of the active site $\mathrm{G}$ and inactive sites due to the 433 dominance of big size Oncholaimus genus (i.e., very low equitability value), the lowest 
434 nematode diversity (species richness) and functional diversity (trophic diversity). In this case, 435 and as reported in Donnarumma et al. (2019) for the macrofauna, the harsh hydrothermal 436 conditions affect the nematode assemblages.

437 Nematodes belonging to the family Oncholaimidae (genus Oncholaimus) have been reported 438 several times inhabiting sediments near to source of the emissions at shallow vents (e.g., Dando 439 et al., 1995; Thiermann et al., 1997; Zeppilli \& Danovaro, 2009). This genus can tolerate high 440 sulphide concentrations by producing sulphur-containing droplets to reduce the toxic effect of 441 hydrogen sulphide (Thiermann et al., 1994, 1997). Oncholaimus has been originally identified as 442 predator/omnivore/scavenger (Jensen, 1987), but recently it has been shown that this nematode 443 can feed also on free-living chemoautotroph microorganisms (Zeppilli et al., 2019). This wide 444 diet makes Oncholaimus able to use the different food sources available at shallow vent: other 445 organisms (as alive or dead animals) and bacterial mat (Thiermann et al., 1997). Oncholaimidae 446 are also known to have symbiotic associations (Bellec et al., 2018; Bellec et al., 2019). The 447 deep-sea nematode Oncholaimus dyvae can harbor sulfur-oxidizing bacteria in the cuticle and in 448 its intestine (Bellec et al., 2018). Metoncholaimus albidus inhabiting shallow water anoxic 449 sediments hosts ectosymbiotic bacteria involved in sulfur metabolism suggesting a potential for 450 chemosynthesis in the nematode microbial community (Bellec et al., 2019). At SdF, 451 Oncholaimus showed endosymbiotic sulfur-oxidizing and -reducing bacteria, purple sulfur 452 bacteria and Zetaproteobacteria in the intestine (Bellec et al., submitted).

453 Moreover, the high abundance and biomass values characterizing Oncholaimus suggested that 454 this nematode could have a significant impact on the turnover of organic matter. Daptonema spl 455 was the second most abundant species at site $\mathrm{H}$; this genus was frequently found at vent areas 456 (Vanreusel et al., 1997; Zeppilli \& Danovaro, 2009). The low trophic diversity index value was 457 the consequence of the dominance of the genera Oncholaimus and Daptonema, but deposit 458 feeders and predators/scavengers are typically reported from shallow vent systems where 459 organisms can feed on available organic resources.

460 The drastic decrease in macrobenthic biodiversity observed at geyser site due to the effect of 461 high sediment temperature and sulfide ions (Donnarumma et al., 2019), was not reported for the 462 nematofauna that showed very low diversity values only at $\mathrm{H}$ site.

463 The nematode diversity at geyser ( 464 geyser hosted its own nematode community characterized by the highest number of exclusive 
465 species (22). While the macrobenthic assemblages around site G was defined as "simplified" 466 community that represented a subset of the background biota (Donnarumma et al., 2019), the 467 presence of sulphur ion $\mathrm{S}^{2-}$ did not constitute a source of disturbance for nematodes structural 468 and functional diversity. According to the ecological theory of 'intermediate disturbance' 469 (Huston, 1979), across an environmental stress gradient higher diversity is expected at 470 intermediate stress levels (i.e., site G), whilst at higher levels of stress only colonizing species 471 survive (i.e., site H). Similarly, Colangelo et al. (2001) reported higher copepod diversity values 472 in areas with moderate gas seepage and sulphur deposits. At site $\mathrm{G}$ we did not observe a clear 473 dominance of one or few genera (i.e., high value of equitability index), and the most represented 474 genera such as Leptolaimus, Desmodora, Paradesmodora and Chromadorita were already 475 reported from other vent areas (Dando et al., 1995; Vanreusel et al., 1997; Zeppilli \& Danovaro, 476 2009).

477 At inactive sites (CN and CS) the family of Desmodoridae (genera Spirinia, Perspiria and 478 Chromaspirina) was the most represented taxon. Those genera, and in particular different species 479 of Spirinia and Chromaspirina, have been reported from different environments spanning from 480 shallow (Platt, 1977; Nicholas et al., 1991; Olafsson, 1995; Vafeiadou et al., 2014) to deep-sea 481 (Da Silva et al., 2009; Leduc and Verschelde, 2015) systems and sometimes associated to 482 unstable condition and coarser sediment, as the sediment at our inactive sites from where we 483 detected the highest percentage of gravel. Another group found at inactive sites was that of 484 Stilbonematinae, reported already from shallow (Kamenev et al., 1993; Thiermann et al., 1994; 485 Dando et al., 1995) and deep-sea vent areas (Vanreusel et al., 1997; Gollner et al., 2010) and 486 inhabiting zones of volcanic activity or at the periphery of vents. Stilbonematine nematodes are 487 common in suitable tropical shallow-water carbonate sands (Ott et al., 2003, 2004), but they are 488 also adapted to life at seeps, organically enriched bottoms (Giere, 2009) and sulphidic sediments 489 where they feed on ectosymbiotic sulphur-oxidizing bacteria (Ott et al., 1991). Stilbonematine 490 nematodes have chemosynthesising ectobacteria covering their bodies, which constitute an 491 adaptation to life in silt enriched with $\mathrm{H}_{2} \mathrm{~S}$ (Powell e a., 1979; Jensen, 1986). We found 492 stilbonematine nematodes at $\mathrm{SdF}$ sediments with their body completely covered by ectobacteria. 493 Their presence at inactive sites, even if in low abundances, suggests the presence of localized 494 and very likely patchy reduced conditions at those sites (Tchesunov et al., 2012) caused by 495 accumulation and burial of dead organic matter. 
496 The trophic structure of assemblages inhabiting the geyser and the inactive site CN was similar 497 to that reported from other shallow vent systems (Kharlamenko et al., 1995; Zeppilli \& 498 Danovaro, 2009), were epistrate feeders dominated because favored by the high primary 499 biomass. The bulk of biomass does not rely solely on symbiotrophs, but on the available organic 500 resources (i.e., deposit feeders, epistrate feeders, predators/omnivores) and this was confirmed 501 also by the significant correlation between TOC content and nematode trophic diversity at SdF. 502 This is particularly true for the inactive site CS where all trophic groups were well represented 503 (i.e., the lowest value of ITD) and therefore underling the ability of nematodes to use all the 504 available food sources and /or to partition multiple food sources (Limén et al., 2007).

505 Vent nematodes belong to families and genera already known from non-vent habitats (Vanreusel 506 et al., 1997; Flint et al., 2006; Zeppilli et al., 2018), suggesting no endemicity at genera or 507 families level for this taxon. However, at a species level many of the nematode present in 508 samples from deep-sea vents appeared to be new, suggesting the presence of unique or endemic 509 species adapted to the vent conditions (Copley et al., 2007; Gollner et al., 2010). In contrast to 510 deep-sea hydrothermal vents, nematode inhabiting shallow vent areas include a subset of species 511 that live in background sediments but can survive in extreme conditions (e.g., Tarasov et al., 512 2005; Zeppilli \& Danovaro, 2009; Zeppilli et al., 2018). However, this is was not the case at SdF 513 vent area where each one of the investigated site (i.e., active H-G and inactive CN-CS sites) was 514 characterized by a distinct nematode community reflecting the high spatial heterogeneity. The $51526 \%$ (at site $\mathrm{CN}$ ) and 28\% (at site CS) of species were unique at the inactive sites, but the highest 516 percentages of exclusive species were found characterizing the active sites $\mathrm{H}(30 \%)$ and $\mathrm{G}$ 517 (38\%). In our study, we noticed a lack of dominance by the nematode genera usually found to be 518 abundant at shallow (e.g., Sabatiera, Linhomoeus, Siphonolaimus, Pomponema, Dichromadora, 519 Paracanthoncus and Steineridora; Dando, Hughes \& Thiermann, 1995; Zeppilli \& Danovaro, 520 2009) and deep-sea (Molgolaimus, Monhystera and Thalassomonhystera; Vanreusel et al., 1997; 521 Zekely et al., 2006) vents, except for the genus Oncholaimus. On the other hand, most of the 522 exclusive genera/species inhabiting the investigated sites are not frequently reported from other 523 vent areas, sustaining the presence of a typical nematofauna assemblage at SdF. Moreover, we 524 noticed a preponderance of monospecific nematode genera in all samples with the 95\% of genera 525 that exhibited a species (i.e., morphotype) to genus ratio of 1 as reported from deep-sea vent 526 systems (Vanreusel et al., 1997; Gollner et al., 2010). 


\section{Effects of SdF vent conditions on meiobenthic comunities}

529 In the recent study of Donnarumma et al. (2019), it has been reported how macrobenthic 530 community structure was significantly correlated with some of the environmental variables (e.g., $531 \mathrm{pH}$, TOC, temperature and interstitial water ions), the same variables that mostly determined the 532 differences between the investigated sites. Similarly, the meiofauna and nematofauna richness 533 and community composition were correlated with the same environmental parameters (Table 3). 534 The effects of sediment temperature, TOC, $\mathrm{pH}$ and ions (e.g., $\mathrm{NO}_{3}{ }^{2-}, \mathrm{Ca}^{2+}$ and $\mathrm{Cl}^{-}$) were 535 particularly clear in influencing patterns of meiofauna and nematofauna communities (Fig. 7 and 536 Fig. 8).

537 Separation between $\mathrm{H}, \mathrm{G}$ and $\mathrm{CN}-\mathrm{CS}$ sites was even more evident when we considered the 538 nematode community composition. The same separation between sites occurred if we considered 539 the macrobenthic community composition (Donnarumma et al., 2019), confirming the 540 importance of key environmental factors for benthic communities such as: sediment temperature, $541 \mathrm{pH}$ value, TOC content and interstitial water characteristics. But if for the macrobenthic 542 community those key factors led to a drastic decrease in density and diversity at both active sites,

543 for the meiofauna and nematofauna assemblage this effect was reported only at $\mathrm{H}$ site where 544 conditions were the most extreme and were few adapted species can survive.

545

546

547

548 This study confirmed some of the trends often observed in vent-associated benthic communities, 549 i.e. a pronounced small-scale spatial variability of meiofauna and particularly nematode 550 composition that reflect the natural patchy distribution of this benthic components and the high 551 environmental heterogeneity of the study area, typically from extreme environments. We noticed 552 a migratory response to deeper layers by the meiofauna due to sediment disturbance (e.g. bubble 553 streams, near-bottom currents, sediment reworking by larger fauna), this is also a common 554 phenomenon reported from such a kind of environment. High nematode biomass values, low 555 diversity and the dominance by the single highly tolerant genus Oncholaimus at station with the 556 harshest conditions $(\mathrm{H})$ was not surprising for vent systems. Other findings, however, appear to 557 contradict some general accepted tenets of shallow water hydrothermal vents ecology. We 558 reported higher values of meiofaunal abundance and diversity characterizing Secca delle Fumose 
559

560

561

562

563

564

565

566

567

568

569

570

571

572

573

574

575

576

577

578

579

580

581

582

583

584

585

586

587

588

589

590

591

592

593

594

595

596

597

598

599

600

shallow vent compared to other shallow vent areas. Nematodes inhabiting sediments of SdF were clearly different and each one of the investigated site was characterized by a distinct nematode community, that means that nematodes at SdF shallow vent did not constitute a subset of species that live in background sediments. In our study, we noticed a lack of dominance by the nematode genera usually found to be abundant at shallow and deep-sea vents, except for Oncholaimus genus, sustaining the presence of a typical nematofauna community at SdF.

\section{Acknowledgments}

We thank the Soprintendenza of the Underwater Archeological Park of Baia (prot. 5667, 24/10/2016) for the authorization to sampling. We are in debt to the diving center Centro SUB Pozzuoli (Guglielmo Fragale) for support during diving activities. We thank Dr. Renato Bruno, Dr. Aurélie Tasiemski and Dr. Céline Boidin-Wichlacz for helping in sampling activities.

\section{References}

Anderson MJ, Gorley RN, Clarke KR. 2008. PERMANOVA+ for PRIMER: guide to software and statistical methods. PRIMER-E Ltd., Plymouth, United Kingdom.

Anderson R, Winter C, Jürgens K. 2012. Protist grazing and viral lysis as prokaryotic mortality factors at Baltic Sea oxic-anoxic interfaces. Marine Ecology Progress Series 467:1-14 DOI: https://doi.org/10.3354/meps10001.

Andrassy I. 1956. The determination of volume and weight of nematodes. Acta Zoologica Hungarica 2: 1-15.

Ansari A, Rivonkar CU, Sangodkar UMX. 2001. Population fluctuation and vertical distribution of meiofauna on a tropical mudfat at Mandovy estuary, west coast of India. Indian Journal of Marine Sciences 30: 237-245 DOI: http://nopr.niscair.res.in/handle/123456789/4627.

Appolloni L, Sandulli R, Vetrano G, Russo GF. 2018. Assessing the effects of habitat patches ensuring propagule supply and different costs inclusion in marine spatial planning through multivariate analyses. Journal of Environmental Management 214, 45-55. doi:10.1016/j.jenvman.2018.02.091.

Bernhard JM, Buck K R, Farmer MA, Bowser SS. 2000. The Santa Barbara Basin is a symbiosis oasis. Nature 403(6765): 77 DOI: https://doi.org/10.1038/47476.

Bezzerra TN, Decraemer W, Eisendle-Flöckner U, Hodda M, Holovachov O, Leduc D, Miljutin D, Mokievsky V, Peña Santiago R, Sharma J, Smol N, Tchesunov A, Venekey V, Zeng Z, Vanreusel A. 2018. NeMys: World Database of Nematodes, available at: http://nemys.ugent.be/ (accessed March, 2018).

Bongers T, Alkemade R, Yeates GW. 1991. Interpretation of disturbance-induced maturity decrease in marine nematode assemblages by means of the Maturity Index. Marine Ecology Progress Series 76: 135-142 DOI: https://www.jstor.org/stable/24825556.

Braeckman U, Provoost P, Moens T, Soetaert K, Middelburg JJ, Vincx M, Vanaverbeke J. 2011. Biological vs. Physical Mixing Effects on Benthic Food Web Dynamics. PLoS ONE 6(3): e18078. DOI:10.1371/journal.pone.0018078. 
601 Cardigos F, Colaço A, Dando PR, Ávila SP, Sarradin PM, Tempera F, Conceição P, Pascoal A, 602 Serraõ SR. 2005. Shallow water hydrothermal vent field fluids and communities of the D.

603

604

605 João de Castro Seamount (Azores). Chemical Geology 224: 153-168 DOI: https://doi.org/10.1016/j.chemgeo.2005.07.019.

Clarke KR, Gorley RN. 2006. User manual/tutorial. PRIMER-E Ltd., Plymouth, UK.

606

607

608

609

610

611

612

613

614

615

616

617

618

619

620

621

622

623

624

625

626

627

628

629

630

631

632

633

634

635

636

637

638

639

640

641

642

643

644

645

Clarke KR, Warwick RM. 2001. Change in Marine Communities: An Approach to Statistical Analysis and Interpretation. PRIMER-E Ltd., Plymouth, UK.

Colangelo MA, Bertasi R, Dall'Olio P, Ceccherelli VH. 2001. Meiofaunal biodiversity on hydrothermal seepage off Panarea (Aeolian Island, Tyrrhenian Sea). In: Faranda FM, Guglielmo L, Spezie G (eds) Structure and processes in Mediterranean ecosystems. SpringerVerlag, Heidelberg, p 353-359.

Copley JTP, Flint HC, Ferrero TJ, Van Dover CL. 2007. Diversity of meiofauna and free-living nematodes in hydrothermal vent mussel beds on the northern and southern East Pacific Rise. Journal of the Marine Biological Association of the United Kingdom 87: 1141-1152 DOI: https://doi.org/10.1017/S0025315407055956.

Coull BC. 1985. Long-term variability in estuarine meiobenthos: an 11 year study. Marine Ecology Progress Series 24:205-218 DOI: https://www.jstor.org/stable/24816886.

D’Auria L, Giudicepietro F, Aquino I, Borriello G, Del Gaudio C, Lo Bascio D, Martini M, Ricciardi G P, Ricciolino P, Ricco C. 2011. Repeated fluid-transfer episodes as a mechanism for the recent dynamics of Campi Flegrei caldera (1989-2010). Journal of Geophysical Research-Solid Earth 116: B04313 DOI:10.1029/2010JB007837.

Da Silva MC, De Castro FJV, Da Fonseca Cavalcanti M, Da Fonseca-Genevois V. 2009. Spirinia lara sp. n. and Spirinia sophia sp. n. (Nematoda, Desmodoridae) from the Brazilian continental margin (Campos Basin, Rio de Janeiro). Zootaxa 2081: 31-45.

Dando PR, Hughes JA, Leathy Y, Niven SJ, Smith C. 1995. Gas venting rates from submarine hydrothermal areas around the Island of Milos, Hellenic Volcanic Arc. Continental Shelf Research 15: 913-929 DOI: https://doi.org/10.1016/0278-4343(95)80002-U.

De Grisse A. 1969. Redescription ou modifications de quelques technique utilisés dans l'etude des nématodes phytoparasitaires. Meded. Rijksfak. LandbWet. Gent 34 : 251-369.

Di Bella L, Ingrassia M, Frezza V, Chiocci FL, Martorelli E. 2016. The response of benthic meiofauna to hydrothermal emissions in the Pontine Archipelago, Tyrrhenian Sea (central Mediterranean Basin). Journl of Marine Systems 164:53-66 DOI: https://doi.org/10.1016/j.jmarsys.2016.08.002.

Donnarumma L, Appolloni L., Chianese E, Bruno R, Baldrighi E, Guglielmo R, Russo GF, Zeppilli D, Sandulli R. 2019. Environemental and benthic community patterns of the shallow hydrothermal area of Secca della Fumose (Baia, Naples, Italy). Frontiers in Marine Science 6:685 DOI: 10.3389/fmars.2019.00685.

Duquette A., James B. McClintock, Charles D. Amsler, Alberto Pérez-Huerta, Marco Milazzo, Jason M. Hall-Spencer 2017. Effects of ocean acidification on the shells of four Mediterranean gastropod species near a CO2 seep. Marine Pollution Bulletin 124 :917-928 DOI: http://dx.doi.org/10.1016/j.marpolbul.2017.08.007.

Eleftheriou A. 2013. Methods for the study of marine benthos. Fourth Edition, ed. A. Eleftheriou John Wiley \& Sons, Ltd.

Fitzsimons MF, Dando PR, Hughes JA, Thiermann F, Akoumianaki I, Pratt SM. 1997. Submarine hydrothermal brine seeps off Milos, Greece. Observations and 
646

647

648

649

650

651

652

653

654

655

656

657

658

659

660

661

662

663

664

665

666

667

668

669

670

671

672

673

674

675

676

677

678

679

680

681

682

683

684

685

686

687

688

689

690 geochemistry. Marine Chemstry 57: 325-340 DOI: https://doi.org/10.1016/S03044203(97)00021-2.

Flint HC, Copley JTP, Ferrero TJ, Van Dover CL. 2006. Patterns of nematode diversity at hydrothermal vents on the East Pacific Rise. Cahiers de Biologie Marine 47:365-370 DOI: https://eprints.soton.ac.uk/id/eprint/35558.

Fricke H, Giere O, Stetter K, Alfredson GA, Kristjansson JK, Stoffers P, Svavarsson J. 1989. Hydrothermal vent communities at the shallow subpolar Mid-Atlantic Ridge. Marine Biology 102: 425-429 DOI: https://doi.org/10.1007/BF00428495.

Gallucci F, Moens T, Vanreusel A, Fonseca G. 2008. Active colonisation of disturbed sediments by deep-sea nematodes: evidence for the patch mosaic model. Marine Ecology Progress Series 367:173-183 DOI:10.3354/meps07537.

Gambi C, Vanreusel A, Danovaro R. 2003. Biodiversity of nematode assemblages from deep-sea sediments of the Atacama Slope and Trench (South Pacific Ocean). Deep Sea Research Part I: Oceanographic Research Papers 50:103-117 DOI: https://doi.org/10.1016/S09670637(02)00143-7.

Giere O. 2009. Meiobenthology. The microscopic motile fauna of aquatic sediments. Berlin, Heidelberg: Springer-Verlag. 527 p.

Gollner S, Riemer B, Martìnez Arbizu P, Le Bris N, Bright M. 2010. Diversity of meiofauna from the $9^{\circ} 50^{\prime} \mathrm{N}$ East Pacific Rise across a gradient of hydrothermal fluid emissions. PLoS ONE 5(8): e12321 DOI:10.1371/journal.pone.0012321.

Gray JS. 2000. The measurement of marine species diversity, with an application to the benthic fauna of the Norwegian continental shelf. Journal of Experimental Marine Biology and Ecology 250: 23-49 DOI: https://doi.org/10.1016/S0022-0981(00)00178-7.

Grego M, Riedel B, Stachowitsch M, De Troch M. 2014. Meiofauna winners and losers of coastal hypoxia: case study harpacticoid copepods. Biogeosciences 11:281-292 DOI: 10.5194/bg-11-281-2014.

Hall-Spencer JM, Rodolfo-Metalpa R, Martin S, Ransome E, Fine M, Turner SM, Rowley SJ, Tedesco D, Buia MC. 2008. Volcanic carbon dioxide vents show ecosystem effects of ocean acidification. Nature 454: 96-99 DOI: 10.1038/nature07051.

Heip C, Vincx M, Vranken G. 1985. The ecology of marine nematodes. Aberdeen University Press.

Heptner MV, Ivanenko VN. 2002. Hydrothermal vent fauna: composition, biology and adaptation. Copepoda. Biology of hydrothermal systems (ed. A. Gebruk), 159-176.

Huston M. 1979. A general hypothesis of species diversity. The American Naturalist 113: 81101. DOI: https://doi.org/10.1086/283366.

Ingels J, Kiriakoulakis K, Wolff GA, Vanreusel A. 2009. Nematode diversity and its relation to the quantity and quality of sedimentary organic matter in the deep Nazare' Canyon, Western Iberian Margin. Deep Sea Research Part I: Oceanographic Research Papers 56:1521-1539 DOI: 10.1016/j.dsr.2009.04.010.

Jensen P. 1987. Feeding ecology of free-living aquatic nematodes. Marine Ecology Progress Series 35:187-196 DOI: www.jstor.org/stable/24825022.

Jones RW. 1993. Preliminary observations on benthonic foraminifera associated with biogenic gas seep in the North Sea. In: Jenkins, D.G. (Ed.), Applied Micropalaeontology. Springer Science, Dordrecht, pp. 69-91.

Peer] reviewing PDF | (2019:12:43903:1:1:NEW 18 Mar 2020) 
691

692

693

694

695

696

697

698

699

700

701

702

703

704

705

706

707

708

709

710

711

712

713

714

715

716

717

718

719

720

721

722

723

724

725

726

727

728

729

730

731

732

733

734

735

Judd AG, Hovland M. 2007. Seabed Fluid Flow: The Impact on Geology, Biology and the Marine Environment. first ed. Cambridge University Press, Cambridge.

Kamenev GM, Fadeev VI, Selin NI, Tarasov VG, Malakhov VV. 1993. Composition and distribution of macro- and meiobenthos around sublittoral hydrothermal vents in the Bay of Plenty, New Zealand. New Zealand Journal of Marine and Freshwater Research 27: 407-418 DOI: https://doi.org/10.1080/00288330.1993.9516582.

Kharlamenko VI, Zhukova NV, Khotimchenko SV, Svetashev VI, Kamenev GM. 1995. Fatty acids as markers of food sources in a shallow-water hydrothermal ecosystem (Kraternaya Bight, Yankich Island, Kurile Islands). Marine Ecology Progress Series 120:231-241 DOI: $10.3354 /$ meps 120231.

Leduc D, Pilditch CA. 2013. Effect of a physical disturbance event on deep-sea nematode community structure and ecosystem function. Journal of Experimental Marine Biology and Ecology 440: 35-41 DOI: http://dx.doi.org/10.1016/j.jembe.2012.11.015.

Leduc D, Verschelde D. 2015. New Spirinia and Stygodesmodora species (Nematoda, Spiriniinae) from the Southwest Pacific, and a revision of the related genera Spirinia, Chromaspirina and Perspiria. European Journal of Taxonomy 118: 1-25 DOI: http://dx.doi.org/10.5852/ejt.2015.118.

Limén H, Levesque C, Juniper SK. 2007. POM in macro-/meiofaunal food webs associated with three flow regimes at deep-sea hydrothermal vents on Axial Volcano, Juan de Fuca Ridge. Marine Biology 153:129-139 DOI: 10.1007/s00227-007-0790-1.

Melwani AR, Kim SL. 2008. Benthic infaunal distributions in shallow hydrothermal vent sediments. Acta Oecologica 33: 162-175 DOI: https://doi.org/10.1016/j. actao.2007.10.008.

Nicholas WL, Elek JA, Stewart AC, Marples TG. 1991. The nematode fauna of a temperate Australian mangrove mudflat; its population density, diversity and distribution . Hydrobiologia 209: 13-27 DOI: https://doi.org/10.1007/BF00006714.

Ólafsson E. 1995. Meiobenthos in mangrove areas in eastern Africa with emphasis on assemblage structure of free-living marine nematodes. Hydrobiologia 312: 47-57. DOI: https://doi.org/10.1007/BF00018886.

Panieri G, Gamberi F, Marani M, Barbieri R. 2005. Benthic foraminifera from a recent, shallowwater hydrothermal environment in the Aeolian Arc (Tyrrhenian Sea). Marine Geology 218: 207-229 DOI: https://doi.org/10.1016/j.margeo.2005.04.002.

Panieri G. 2006a. The effect of shallow marine hydrothermal vent activity on benthic foraminifera (Aeolian Arc, Tyrrhenian Sea). The Journal of Foraminiferal Research 36: 314 DOI: https://doi.org/10.2113/36.1.3.

Panieri G. 2006b. Foraminiferal response to an active methane seep environment: a case study from the Adriatic Sea. Marine Micropaleontology 61: 116-130 DOI: https://doi.org/10.1016/j.marmicro.2006.05.008.

Pichler TP, Veizer J, Hall GEM. 1999. The chemical composition of shallow-water hydrothermal fluids in Tatum Bay, Ambitle Island, Papua New Guinea and their effect on ambient water. Marine Chemstry 64: 229-252 DOI: https://doi.org/10.1016/S0304-4203(98)00076-0.

Pielou EC. 1975. Ecological diversity. Wiley, New York.

Platt HM, Warwick RM. 1983. A Synopsis of the Free Living Marine Nematodes. Part I: British Enoplids. Cambridge University Press, Cambridge.

Platt HM, Warwick RM. 1988. Free-living marine nematodes: Part II. British chromadorids. EJ Brill, Dr. W. Backhuys for the Linnean Society of London and the Estuarine and Brackish- 
736

737

738

739

740

741

742

743

744

745

746

747

748

749

750

751

752

753

754

755

756

757

758

759

760

761

762

763

764

765

766

767

768

769

770

771

772

773

774

775

776

777

778

779 water Sciences Association Synopses of the British Fauna No. 38. Cambridge University Press, Cambridge.

Platt HM. 1977. Vertical and horizontal distribution of free-living marine nematodes from Strangford Lough, Northern Ireland. Cahiers de Biologie Marine, Tome XVIII, pp. 261-273.

Prol-Ledesma RM, Canet C, Torres-Vera MA, Forrest MJ, Armienta MA. 2004. Vent fluid chemistry in Bahia Concepcion coastal submarine hydrothermal system, Baja California Sur, Mexico. Journal of Volcanology and Geothermal Research 137: 311-328. DOI: https://doi.org/10.1016/j.jvolgeores.2004.06.003.

Riemann F, Thiermann F, Bock L. 2003. Leptonemella species (Desmodoridae, Stilbonematinae), benthic marine nematodes with ectosymbiotic bacteria, from littoral sand of the North Sea island of Sylt: taxonomy and ecological aspects. Helgoland Marine Research 57: 118-131 DOI: https://doi.org/10.1007/s10152-003-0149-z.

Rosli N, Leduc D, Rowden AA, Clark MR, Probert PK, Berkenbusch K, Neira C. 2016. Differences in meiofauna communities with sediment depth are greater than habitat effects on the New Zealand continental margin: implications for vulnerability to anthropogenic disturbance. PeerJ 4:e2154 DOI: 10.7717/peerj.2154.

Sandulli R, Miljutin D, Angeletti L, Taviani M. 2015. Meiobenthos and nematode assemblages from different deep-sea habitats of the Strait of Sicily (Central Mediterranean Sea). Mediterranean Marine Science 16: 402-412 DOI: http://dx.doi.org/10.12681/mms.1145.

Schumacher BA. 2002. Methods for the determination of total organic carbon (TOC) in soils and sediments. NCEA-C- 1282 EMASC-001.

Scrosati R, Heaven C. 2007. Spatial trends in community richness, diversity, and evenness across rocky intertidal environmental stress gradients in eastern Canada. Marine Ecology

Progress Series 342: 1-14 DOI: 10.3354/meps342001.

Sorokin, YuI, Sorokin PYu, Zakuskina OYu. 1998. Microplankton and its functional activity in zones of shallow hydrotherms in the western Pacific. Journal of Plankton Research 20:10151031 DOI: https://doi.org/10.1093/plankt/20.6.1015.

Steyaert M, Vanaverbeke J, Vanreusel A, Barranguet C, Lucas C, Vincx M. 2003. The importance of fine-scale, vertical profiles in characterising nematode community structure. Estuarine, Coastal and Shelf Science 58: 353-366 DOI: https://doi.org/10.1016/S0272-7714(03)00086-6.

Tarasov VG, Gebruk AV, Mironov AN, Moskalev LI. 2005. Deep-sea and shallow-water hydrothermal vent communities: two different phenomena? Chemical Geology 224: 5-39 DOI: https://doi.org/10.1016/j.chemgeo.2005.07.021.

Tarasov VG, Gebruk AV, Mironov AN, Moskalev LI. 2005. Deep-sea and shallow-water hydrothermal vent communities: two different phenomena? Chemical Geology 224: 5-39 DOI: https://doi.org/10.1016/j.chemgeo.2005.07.021.

Tarasov VG, Gebruk AV, Shulkin VM, Kamenev GM, Fadeev VI, Kosmynin VN, Malakhov VV, Starynin DA, Obzhirov AI. 1999. Effect of shallow-water hydrothermal venting on the biota of Matupi Harbour (Rabaul Caldera, New Britain Island, Papua New Guinea). Continental Shelf Research 19: 79-116 DOI: https://doi.org/10.1016/S0278-4343(98)000739.

Tchesunov AV, Schmidt-Rhaesa A. (2014). Handbook of zoology. Gastrotricha, Cycloneuralia, Gnathifera. Volume 2: Nematoda.

Peer] reviewing PDF | (2019:12:43903:1:1:NEW 18 Mar 2020) 
780

781

782

783

784

785

786

787

788

789

790

791

792

793

794

795

796

797

798

799

800

801

802

803

804

805

806

807

808

809

810

811

812

813

814

815

816

817

818

819

820

821

822

823

824

825

Tchesunov AV. 2013. Marine free-living nematodes of the subfamily Stilbonematinae (Nematoda, Desmodoridae): taxonomic review with descriptions of a few species from the Nha Trang Bay, Central Vietnam. Meiofauna Marina 20: 71-94.

Tchesunov AV. 2015. Free-living nematode species (Nematoda) dwelling in hydrothermal sites of the North Mid-Atlantic Ridge. Helgoland Marine Research 69: 343-384 DOI: 10.1007/s10152-015-0443-6.

Teixidó N, Gambi MC, Parravacini V, Kroeker K, Micheli F, Villéger S, Ballesteros E. 2019. Functional biodiversity loss along natural CO2 gradients. Nature Communications 9:5149 DOI: $10.1038 / \mathrm{s} 41467-018-07592-1$.

Thiermann F, Akoumianaki I, Hugjes AJ, Giere O. 1997. Benthic fauna of a shallow-water gaseohydrothermal vent area in the Aegean Sea (Milos, Greece). Marine Biology 128 149159 DOI: https://doi.org/10.1007/s002270050078.

Thiermann F, Windoffer R, Giere O. 1994. Selected meiofauna around shallow water hydrothermal vents off Milos (Greece): ecological and ultrastructural aspects. Vie Milieu 44: 215-226.

Todesco M. 2009. Signals from the Campi Flegrei hydrothermal system: Role of a "magmatic" source of fluids. Journal of Geophysical Research-Solid Earth 114: B05201 DOI:10.1029/2008JB006134.

Vafeiadou AM, Materatski P, Adão H, De Troch M, Moens T. 2014. Resource utilization and trophic position of nematodes and harpacticoid copepods in and adjacent to Zostera noltii beds. Biogeosciences 11:4001-4014 DOI:10.5194/bg-11-4001-2014.

Vanreusel A, De Groote A, Gollner S, Bright M. 2010. Ecology and biogeography of free-living nematodes associated with chemosynthetic environments in the deep sea: a review. PLoS ONE 5(8):e12449 DOI:10.1371/journal.pone.0012449.

Vanreusel A, Van den Bossche I, Thiermann F. 1997. Free-living marine nematodes from hydrothermal sediments: similarities with communities from diverse reduced habitats. Marine Ecology Progress Series 157:207-219 DOI: 10.3354/meps157207.

Vanreusel, A, Van den Bossche I, Thiermann F. 1997. Free-living marine nematodes from hydrothermal sediments: similarities with communities from diverse reduced habitats. Marine Ecology Progress Series 157: 207-219 DOI: 10.3354/meps157207.

Warwick RM, Platt HM, Somerfield PJ. (1998). A synopsis of the free living marine nematodes. Part III: monhysterids. Synopses of the British Fauna (New Series). Field Studies Council, Shwreusbury.

Wieser W. 1953. Die Beziehung zwischen Mundhöhlengestalt, Ernährungsweise und Vorkommen bei freilebenden marinen Nematoden. Arkiv för Zoologi 2/4: 439-484.

Wildish DJ, Akagi HM, McKeown DL, Pohle GW. 2008. Pockmarks influence benthic communities in Passamaquoddy Bay, Bay of Fundy, Canada. Marine Ecology Progress Series 357: 51-66 DOI: https://doi.org/10.3354/meps07331.

Zeppilli D, Bellec L, Cambon-Bonavita MA, Decraemer W, Fontaneto D, Fuchs S, Gayet N, Mandon P, Michel LN, Portail M, Smol N, Sørensen MV, Vanreusel A, Sarrazin J. 2019. Ecology and trophic role of Oncholaimus dyvae sp. nov. (Nematoda: Oncholaimidae) from the lucky strike hydrothermal vent field (Mid-Atlantic Ridge). BMC Zoology 4:6 DOI: https://doi.org/10.1186/s40850-019-0044-y.

Zeppilli D, Leduc D, Fontanier C, Fontaneto D, Fuchs S, Gooday AJ, Goineau A, Ingels J, Ivanenko VN, Kristensen RM, Neves RC, Sanchez N, Sandulli R, Sarrazin J, Sørensen MV, Tasiemski A, Vanreusel A, Autret M, Bourdonnay L, Claireaux M, Coquillé V, De Wever L, 
826

827

828

829

830

831

832

833

834

835

836

837

838

839

840

841

842

843

844

845

846

847

848

849

850

851

852

853

854

855

856

857

858

859

860

861

862

863

864

865

866

867

868

869

870
Rachel D, Marchant J, Toomey L, Fernandes D. 2018. Characteristics of meiofauna in extreme marine ecosystems: a review. Marine Biodiversity DOI:

https://doi.org/10.1007/s12526-017-0815-z.

Figure titles and legends

Figure 1. Map showing the location of the sampling area Secca delle Fumose in underwater park of Baia MPA located in the Gulf of Naples (Tyrrhenian sea, Italy). Selected sampling sites are: the diffusive emission site $(\mathrm{H})$ called "White" for the presence of white microbial mats; the geyser site $(\mathrm{G})$ called "Yellow" for the sulphur deposits; the inactive sites north $(\mathrm{CN})$ and south (CS). The different habitats are indicated as follow: AP-C = photophilous algae and sciaphilous cavities; SGCF = coarse sands and fine gravels; SVMC = superficial muddy sands. The base map was performed using a Side Scan Sonar (SSS) Klein $3900-450 \mathrm{kHz}$. The SSS used 2 transducers to transmit a high-frequency acoustic signal towards the sea floor and the return signal was picked up by the SSS and transmitted in real time to a graphic recorder on board ship. The ship's position was continuously recorded from a positioning satellite system (DGPS and Gyro GNSS Hemisphere Vector gnss VS 330). SSS and navigation data were processed using SonarProß.

Figure 2. Total meiofaunal and nematode abundances. Reported are mean values $( \pm \mathrm{SD})$ at all investigated sites: the diffusive emission site $(\mathrm{H})$; the geyser site $(\mathrm{G})$; the inactive sites north $(\mathrm{CN})$ and south $(\mathrm{CS})$.

Figure 3. Vertical distribution of total meiofaunal and nematode abundances. Reported are mean values $( \pm \mathrm{SD})$ at four sampling sites $(\mathrm{A}-\mathrm{D})$.

Figure 4. Cluster analysis with SIMPROF test performed on meiofaunal community composition. Red lines indicate statistically significant groupings according to the SIMPROF routine. All replicates are shown and indicated as: $\mathrm{H} 1, \mathrm{H} 2$ and H3; G1, G2 and G3; CN1, CN2 and CN3; CS1, CS2 and CS3.

Figure 5. Meiofauna taxonomic composition. Others: Bivalvia, Gasteropoda, Scaphopoda, Polyplacophora, Oligochaeta, Amphipoda, Isopoda, Cumacea, Tanaidacea, Cladocera, Halacarida, Tardigrada, Kinorhyncha, Gastrotricha, Platyhelminthes, Nemertea, Sipuncula, Porifera, Rotifera, Cnidaria and Chaetognatha.

Figure 6. Vertical meiofauna taxonomic composition at four sampling sites (A-D). Others: Bivalvia, Gasteropoda, Scaphopoda, Polyplacophora, Oligochaeta, Amphipoda, Isopoda, Cumacea, Tanaidacea, Cladocera, Halacarida, Tardigrada, Kinorhyncha, Gastrotricha, Platyhelminthes, Nemertea, Sipuncula, Porifera, Rotifera, Cnidaria and Chaetognatha .

Figure 7. Cluster analysis with SIMPROF test performed on nematode composition. Red lines indicate statistically significant groupings according to the SIMPROF routine. All replicates are shown and indicated as: $\mathrm{H} 1, \mathrm{H} 2$ and $\mathrm{H} 3$; G1, G2 and G3; CN1, CN2 and CN3; CS1, CS2 and CS3. 
871 Figure 8. Nematode trophic structure characterizing all investigated sites. Reported are 1A 872 (selective deposit feeders), 1B (non-selective deposit feeders), 2A (epigrowth feeders) and 2B

873 (predators/omnivores) at the four sampling sites.

874

875

Figure 9. dbRDA canonical model on meiofauna taxonomic composition. The graph shows

876 the effect of environmental variables on meiofauna taxonomic composition based on Spearman

877 rank correlations.

878

879

Figure 10. dbRDA canonical model on nematode community composition. The graph shows the effect of environmental variables on nematode community composition based on Spearman

881 rank correlations.

882

883

884

885

886

887

888

889

890

891

892

893

894 


\section{Figure 1}

Figure 1. Map showing the location of the sampling area Secca delle Fumose in underwater park of Baia MPA located in the Gulf of Naples (Tyrrhenian sea, Italy).

Selected sampling sites are: the diffusive emission site (H) called "White" for the presence of white microbial mats; the geyser site (G) called "Yellow" for the sulphur deposits; the inactive sites north (CN) and south (CS). The different habitats are indicated as follow: AP-C = photophilous algae and sciaphilous cavities; SGCF = coarse sands and fine gravels; SVMC = superficial muddy sands. The base map was performed using a Side Scan Sonar (SSS) Klein 3900 - $450 \mathrm{kHz}$. The SSS used 2 transducers to transmit a high-frequency acoustic signal towards the sea floor and the return signal was picked up by the SSS and transmitted in real time to a graphic recorder on board ship. The ship's position was continuously recorded from a positioning satellite system (DGPS and Gyro GNSS Hemisphere Vector gnss VS 330). SSS and navigation data were processed using SonarPro ${ }^{\circledR}$. 


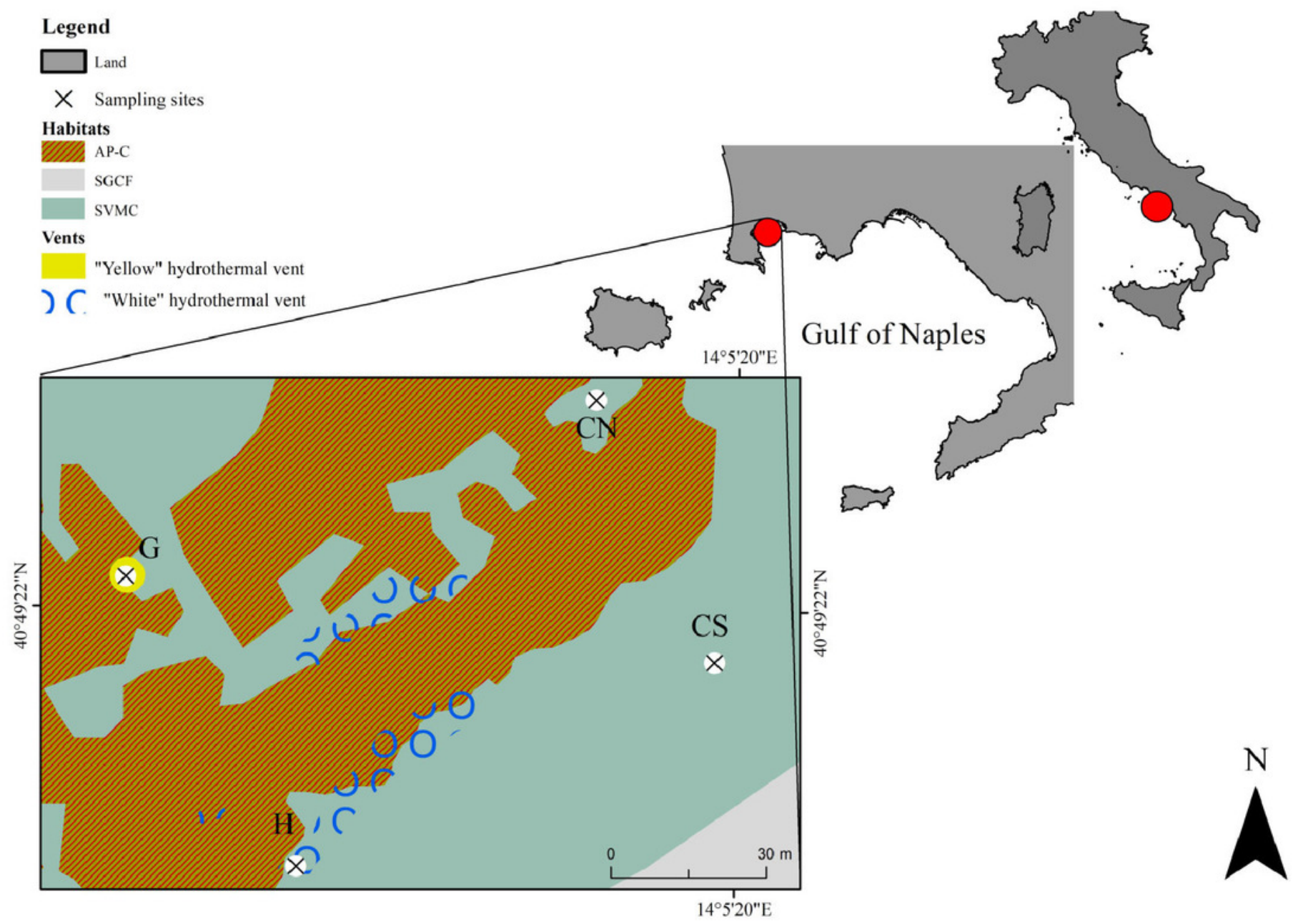


Figure 2

Total meiofaunal and nematode abundances.

Reported are mean values $( \pm S D)$ at all investigated sites: the diffusive emission site $(H)$; the geyser site (G); the inactive sites north (CN) and south (CS).

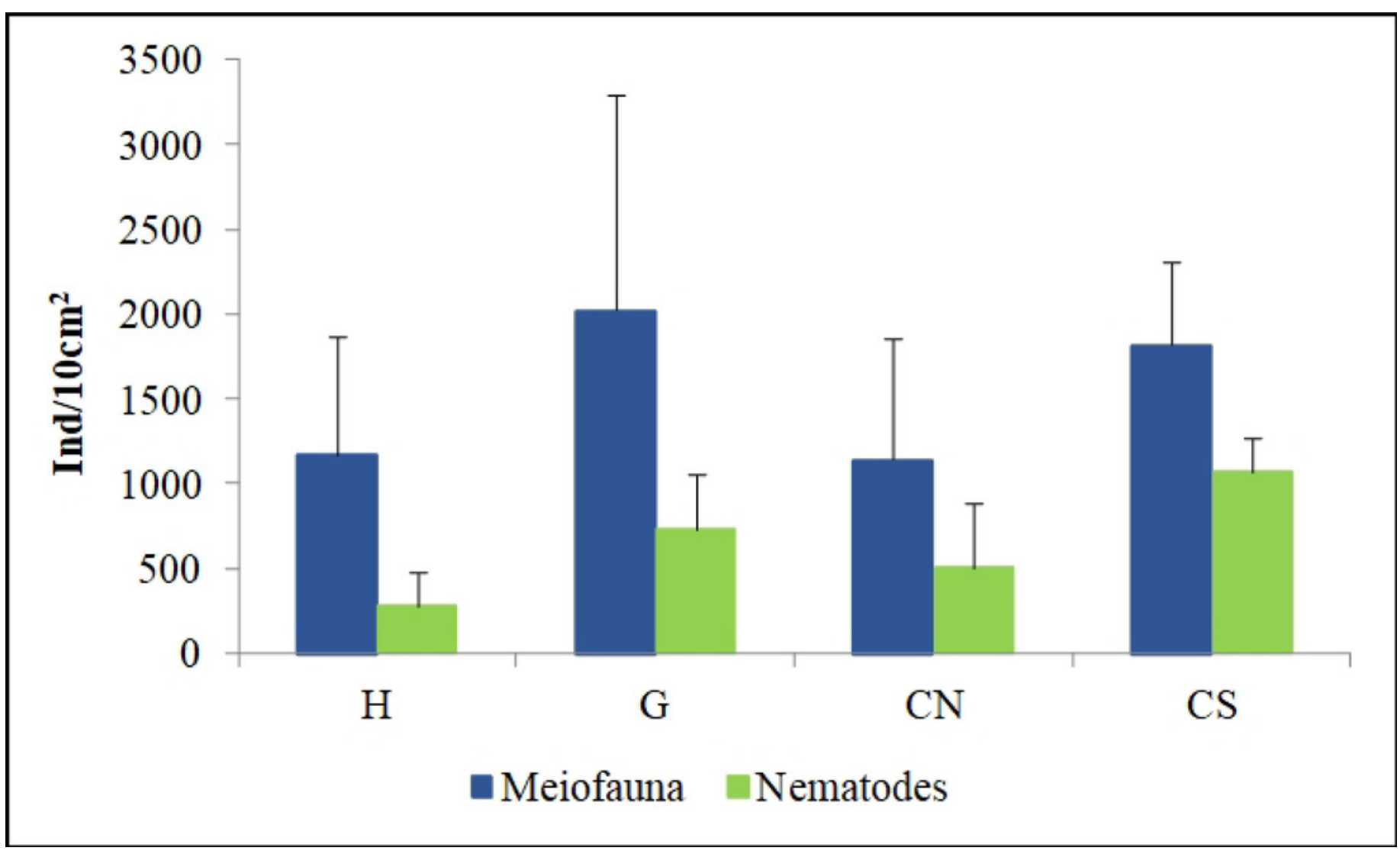


Figure 3

Vertical distribution of total meiofaunal and nematode abundances.

Reported are mean values $( \pm S D)$ at four sampling sites $(A-D)$.
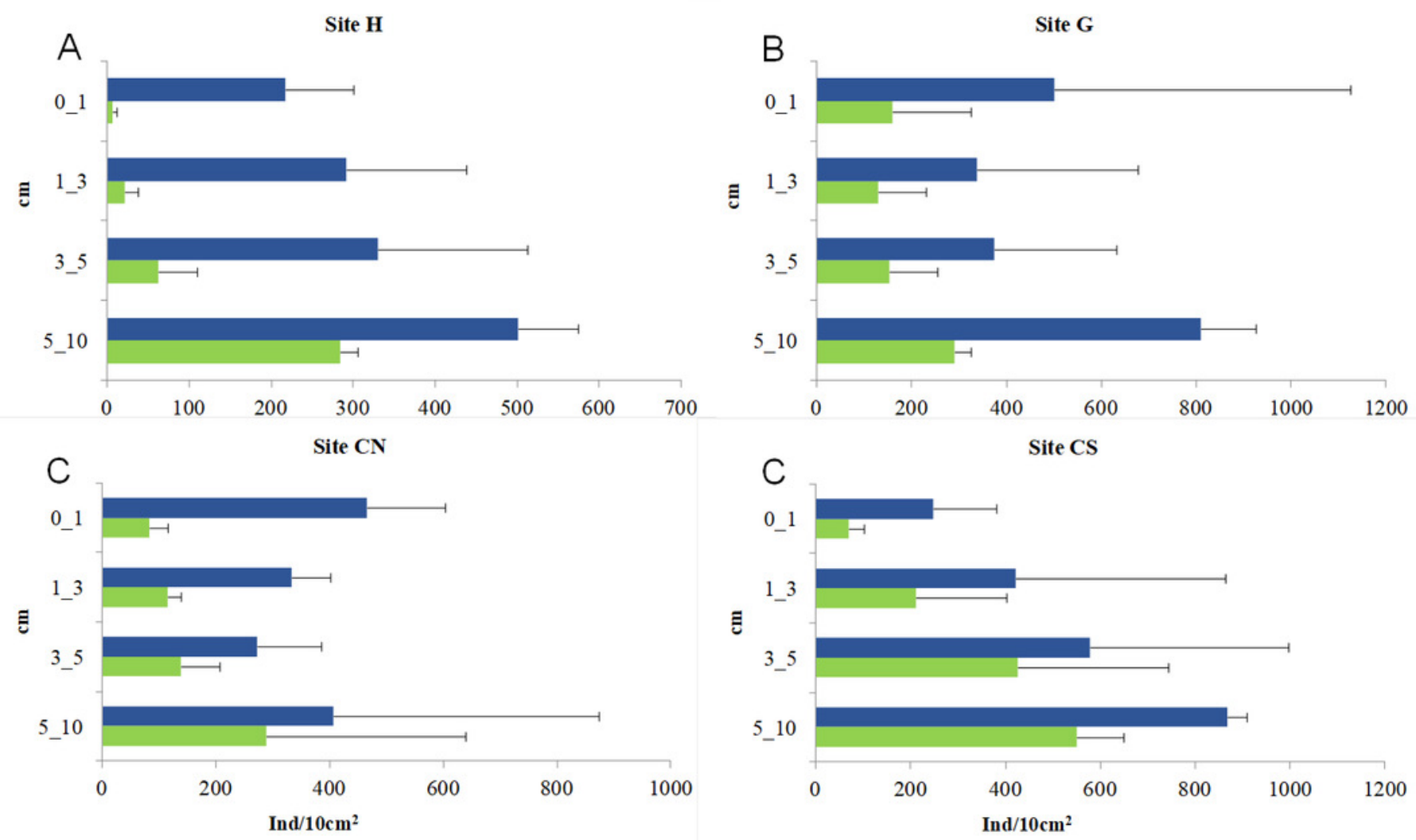

Meiofauna

Nematodes 
Figure 4

Figure 4. Cluster analysis with SIMPROF test performed on meiofaunal community composition.

Red lines indicate statistically significant groupings according to the SIMPROF routine. All replicates are shown and indicated as: $\mathrm{H1}, \mathrm{H} 2$ and $\mathrm{H} 3 ; \mathrm{G} 1, \mathrm{G} 2$ and $\mathrm{G} 3$; $\mathrm{CN1}, \mathrm{CN} 2$ and $\mathrm{CN} 3$; CS1, CS2 and CS3.

Group average

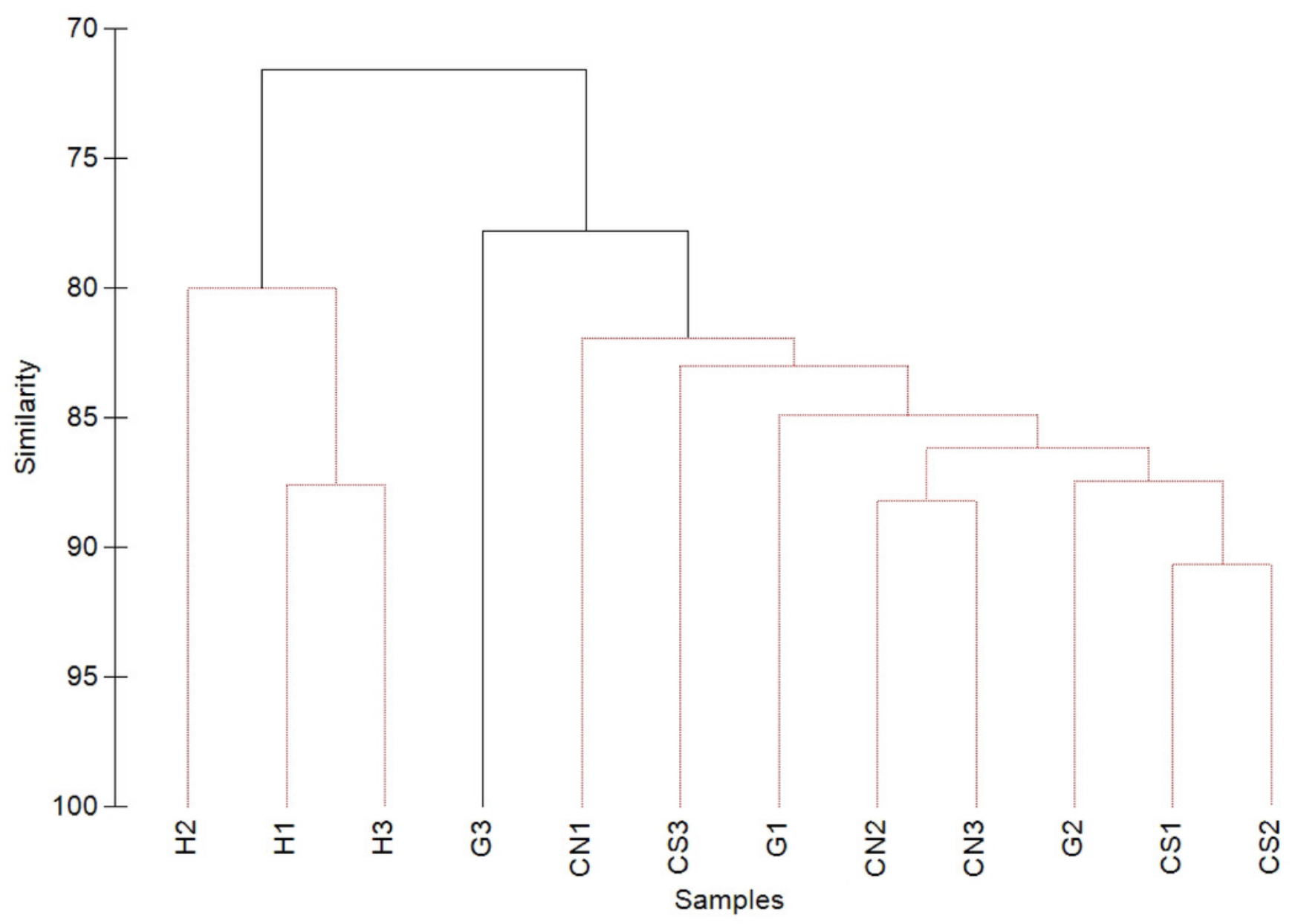


Figure 5

Meiofauna taxonomic composition

Others: Bivalvia, Gasteropoda, Scaphopoda, Polyplacophora, Oligochaeta, Amphipoda, Isopoda, Cumacea, Tanaidacea, Cladocera, Halacarida, Tardigrada, Kinorhyncha, Gastrotricha, Platyhelminthes, Nemertea, Sipuncula, Porifera, Rotifera, Cnidaria and Chaetognatha.

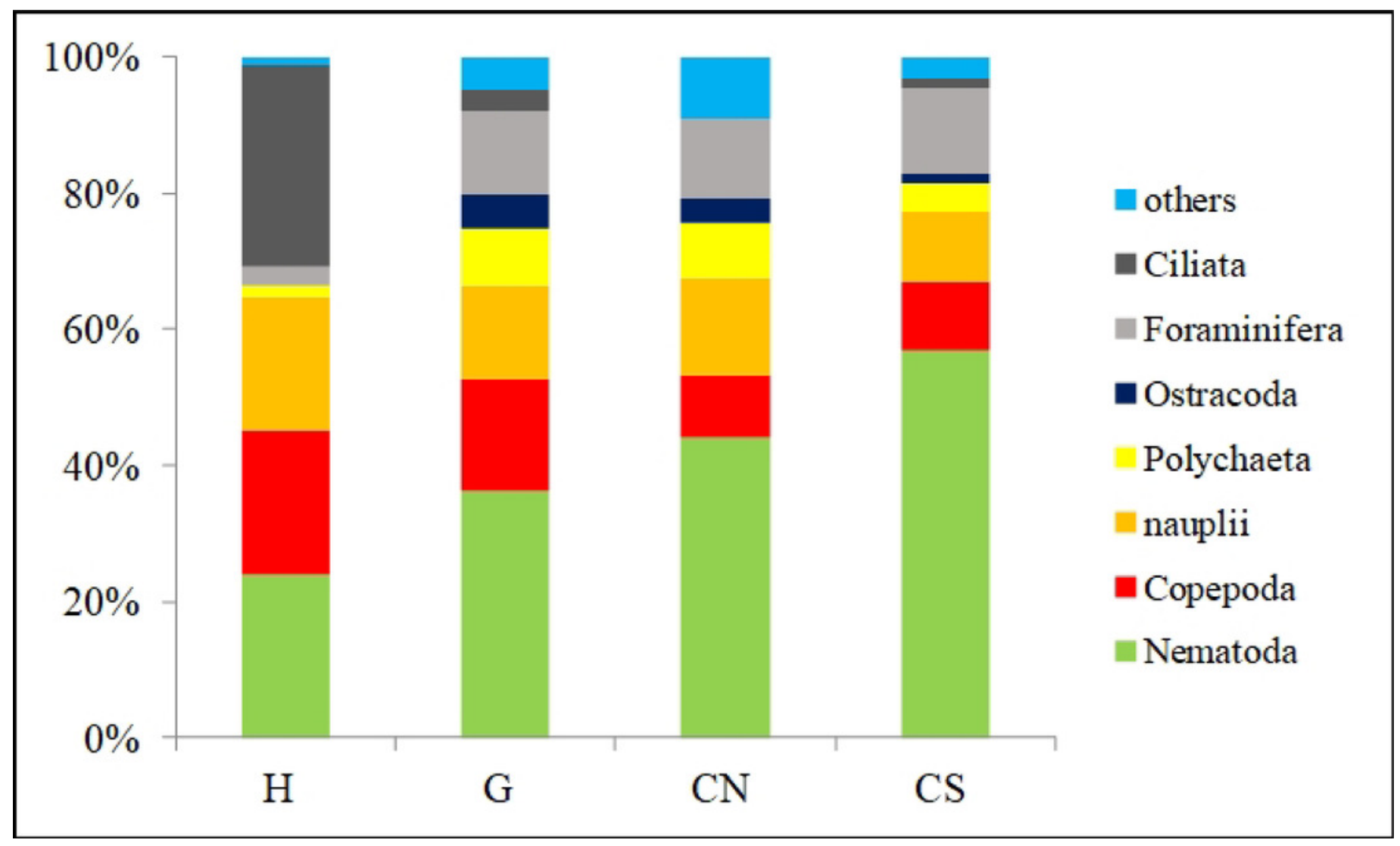




\section{Figure 6}

Vertical meiofauna taxonomic composition four sampling sites (A-D).

Others: Bivalvia, Gasteropoda, Scaphopoda, Polyplacophora, Oligochaeta, Amphipoda, Isopoda, Cumacea, Tanaidacea, Cladocera, Halacarida, Tardigrada, Kinorhyncha, Gastrotricha, Platyhelminthes, Nemertea, Sipuncula, Porifera, Rotifera, Cnidaria and Chaetognatha.

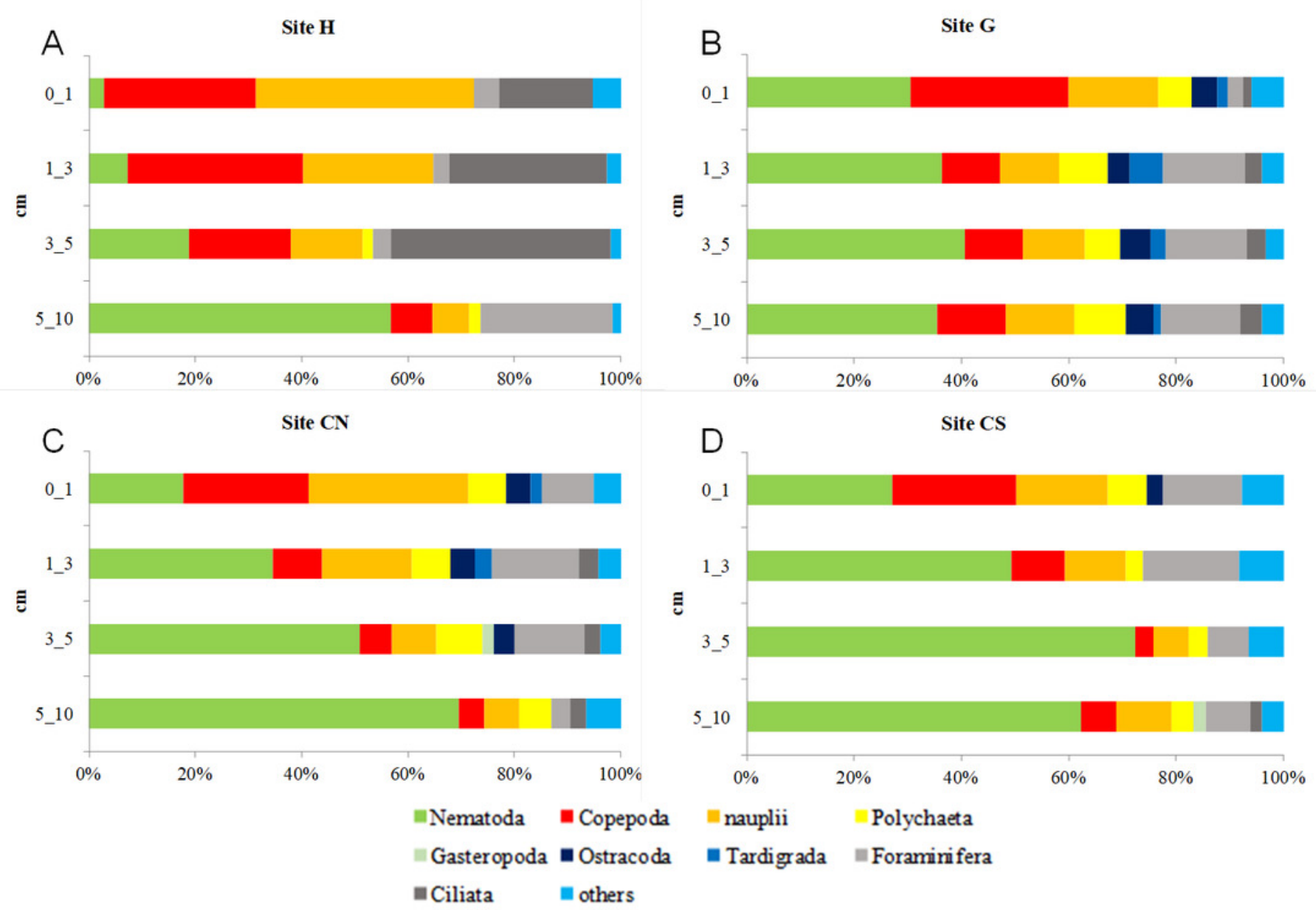


Figure 7

Cluster analysis with SIMPROF test performed on nematode composition.

Red lines indicate statistically significant groupings according to the SIMPROF routine. All replicates are shown and indicated as: $\mathrm{H} 1, \mathrm{H} 2$ and $\mathrm{H} 3 ; \mathrm{G} 1, \mathrm{G} 2$ and $\mathrm{G} 3 ; \mathrm{CN1}, \mathrm{CN} 2$ and $\mathrm{CN} 3$; CS1, CS2 and CS3.

Group average

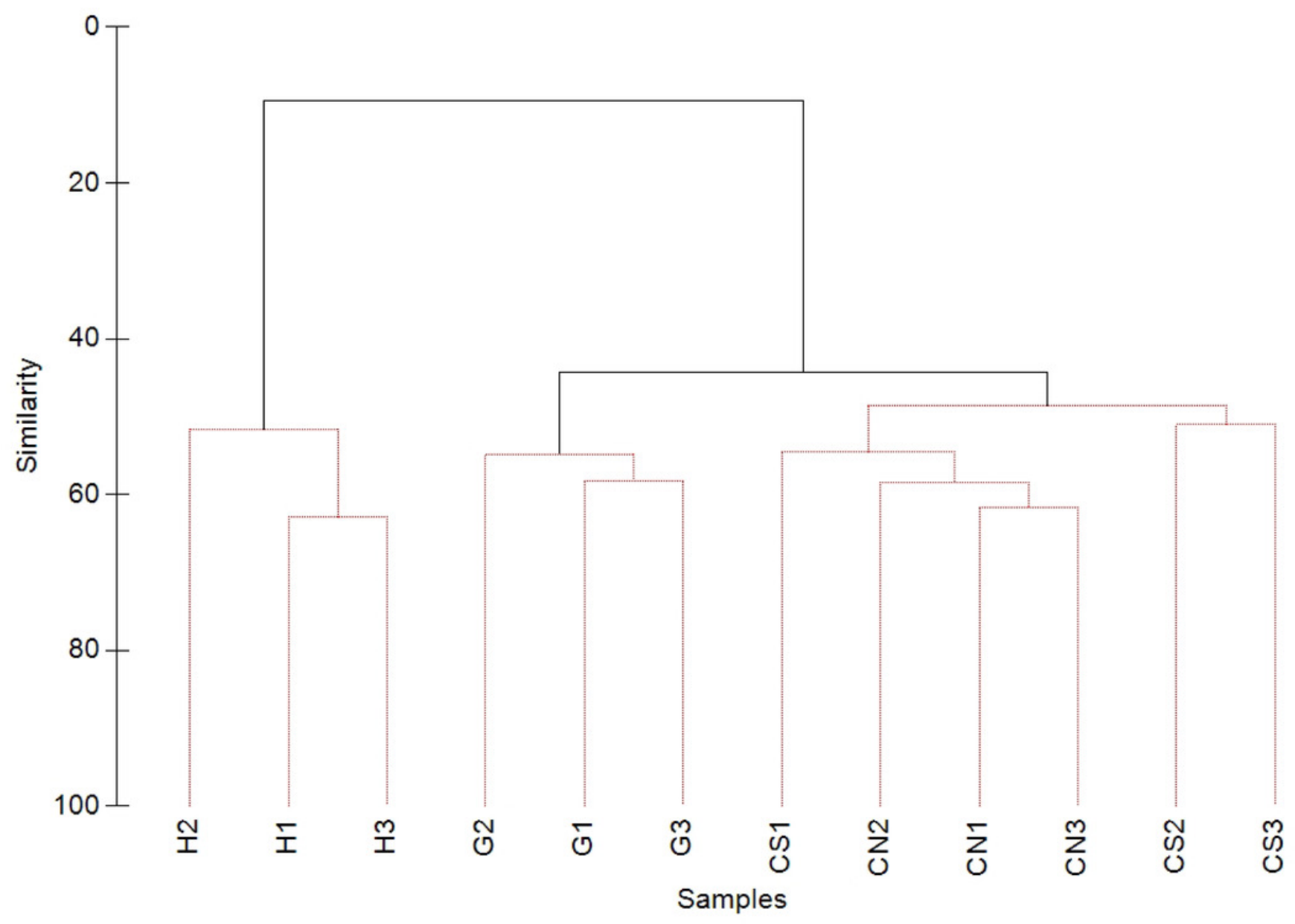


Figure 8

Nematode trophic structure characterizing all investigated sites.

Reported are 1A (selective deposit feeders), 1B (non-selective deposit feeders), 2A (epigrowth feeders) and 2B (predators/omnivores) at the four sampling sites.

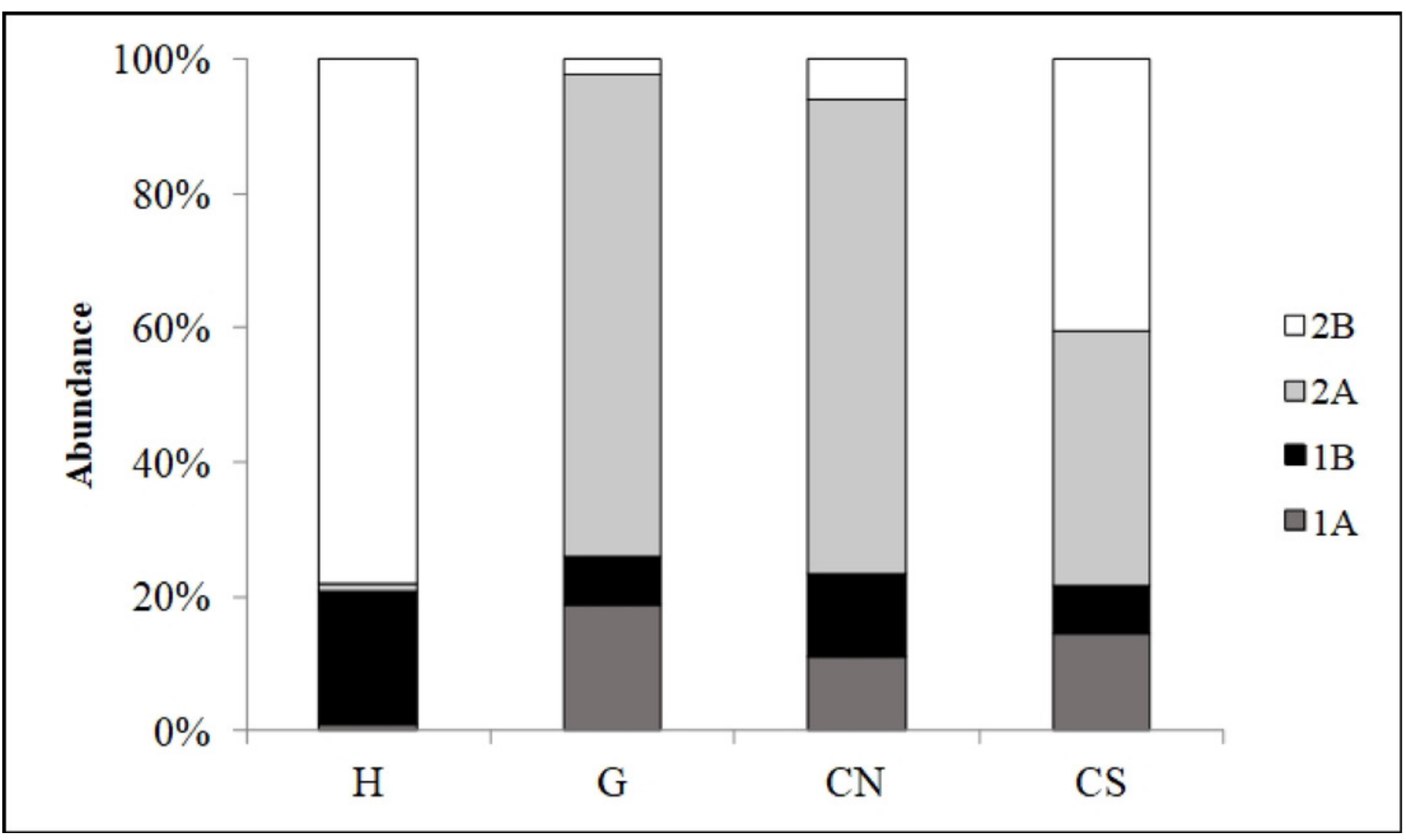


Figure 9

dbRDA canonical model on meiofauna taxonomic composition.

The graph shows the effect of environmental variables on meiofauna taxonomic composition based on Spearman rank correlations.

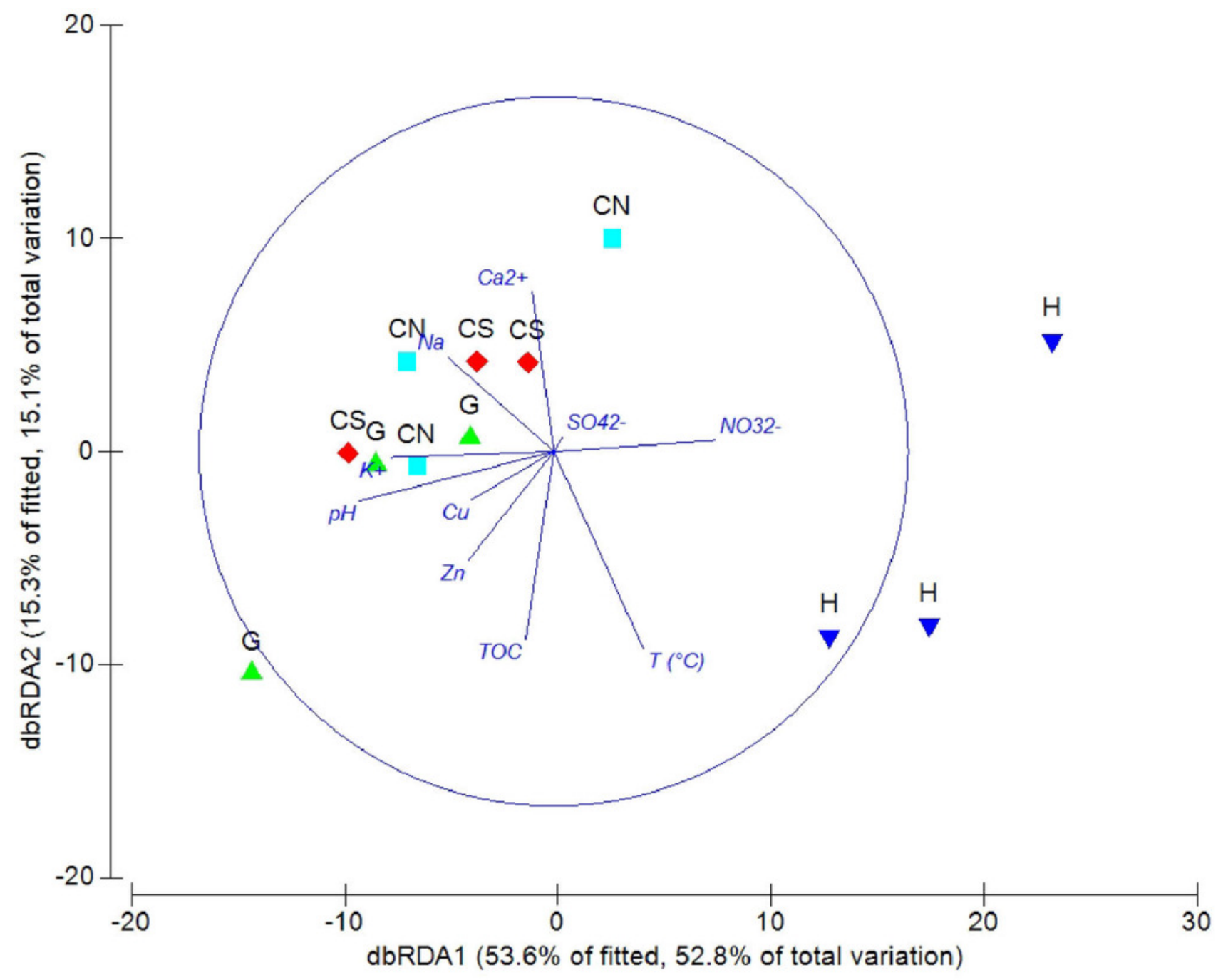


Figure 10

dbRDA canonical model on nematode community composition.

The graph shows the effect of environmental variables on nematode community composition based on Spearman rank correlations.

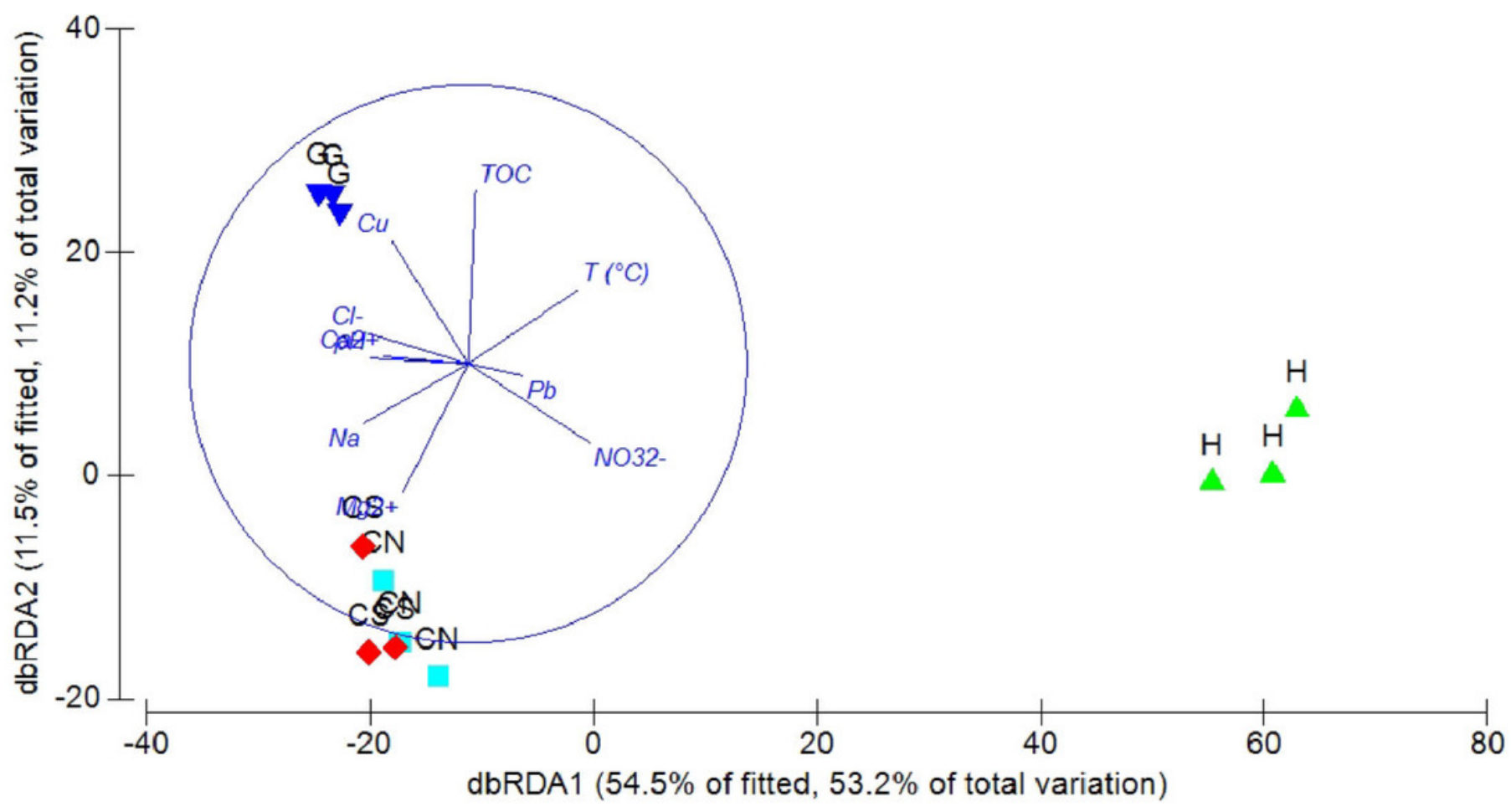




\section{Table $\mathbf{1}$ (on next page)}

Results of PERMANOVA and PAIR-WISE tests for differences in meiofaunal abundance, number of taxa, meiofaunal taxonomic composition, nematode biomass and nematode species composition among sites (S) and layers (L).

Reported are (A) results of PERMANOVA Main tests and (B) Pair-wise tests. Df, degree of freedom; F, F-statistic; ns, not significant. 
Table 1: Results of PERMANOVA and PAIR-WISE tests for differences in meiofaunal abundance, number of taxa, meiofaunal taxonomic composition, nematode biomass and nematode species composition among sites (S) and layers (L). Reported are (A) results of PERMANOVA Main tests and (B) Pair-wise tests. Df, degree of freedom; F, F-statistic; ns, not significant.

\begin{tabular}{|c|c|c|c|c|c|c|c|c|c|}
\hline A) & Source & $\mathrm{df}$ & MS & $\mathrm{F}$ & $\mathrm{P}$ & B) & Source & & $\mathrm{P}$ \\
\hline $\begin{array}{l}\text { Total } \\
\text { meiofauna }\end{array}$ & Site & 3 & 1.194 & 1.244 & ns & Meiofaunal & Site & $H$ vs $G$ & 0.001 \\
\hline \multirow[t]{4}{*}{ abundance } & Layer & 3 & 2.243 & 2.337 & ns & $\mathbf{n}^{\circ} \operatorname{taxa}$ & & $\mathrm{H}$ vs $\mathrm{CN}$ & 0.001 \\
\hline & SxL & 9 & 0.591 & 0.616 & ns & & & $\mathrm{H}$ vs CS & 0.001 \\
\hline & Residual & 29 & 0.960 & & & Meiofaunal & Site & $\mathrm{H}$ vs $\mathrm{G}$ & 0.009 \\
\hline & Total & 44 & & & & composition & & $\mathrm{H}$ vs $\mathrm{CN}$ & 0.002 \\
\hline Meiofaunal & Site & 3 & 6.079 & 14.632 & 0.001 & & & $\mathrm{H}$ vs $\mathrm{CS}$ & 0.006 \\
\hline \multirow[t]{4}{*}{$n^{\circ} \operatorname{taxa}$} & Layer & 3 & 1.049 & 2.524 & $\mathrm{~ns}$ & Total nematode & Site & $\mathrm{H}$ vs $\mathrm{G}$ & 0.024 \\
\hline & $\mathrm{SxL}$ & 9 & 1.053 & 2.535 & 0.023 & abundance & & $\mathrm{H}$ vs $\mathrm{CS}$ & 0.006 \\
\hline & Residual & 29 & 0.415 & & & & Layer & $0-1$ vs $5-10$ & 0.001 \\
\hline & Total & 44 & & & & & (within levels & $1-3$ vs $5-10$ & 0.002 \\
\hline Meiofaunal & Site & 3 & 69.482 & 2.5462 & 0.002 & & $\mathrm{H}$ and $\mathrm{CS}$ ) & & \\
\hline \multirow[t]{4}{*}{ composition } & Layer & 3 & 30.437 & 1.1154 & ns & Total nematode & Site & $\mathrm{H}$ vs $\mathrm{G}$ & 0.001 \\
\hline & SxL & 9 & 24.074 & 0.8822 & ns & biomass & & $\mathrm{H}$ vs $\mathrm{CN}$ & 0.005 \\
\hline & Residual & 29 & 27.289 & & & & & $\mathrm{H}$ vs $\mathrm{CS}$ & 0.026 \\
\hline & Total & 44 & & & & & & $\mathrm{G}$ vs $\mathrm{CN}$ & 0.002 \\
\hline Total nematode & Site & 3 & 2.953 & 5.067 & 0.007 & & & G vs CS & 0.001 \\
\hline \multirow[t]{4}{*}{ abundance } & Layer & 3 & 4.622 & 7.931 & 0.001 & & Layer & $0-1$ vs $3-5$ & 0.012 \\
\hline & SxL & 9 & 0.556 & 0.954 & ns & & (within levels & $0-1$ vs $5-10$ & 0.001 \\
\hline & Residual & 29 & 0.583 & & & & $\mathrm{H}, \mathrm{G}$ and $\mathrm{CN})$ & $1-3$ vs $3-5$ & 0.014 \\
\hline & Total & 44 & & & & & & $1-3$ vs $5-10$ & 0.001 \\
\hline Total nematode & Site & 3 & 12.539 & 4.180 & 0.001 & Nematode & Site & $\mathrm{H}$ vs $\mathrm{G}$ & 0.001 \\
\hline \multirow[t]{4}{*}{ biomass } & Layer & 3 & 9.366 & 3.122 & 0.001 & composition & & $\mathrm{H}$ vs $\mathrm{CN}$ & 0.001 \\
\hline & SxL & 9 & 15.528 & 1.725 & 0.001 & & & $\mathrm{H}$ vs $\mathrm{CS}$ & 0.001 \\
\hline & Residual & 29 & 9.012 & 0.311 & & & Site & $\mathrm{G}$ vs $\mathrm{CN}$ & 0.001 \\
\hline & Total & 44 & 44.000 & & & & & G vs CS & 0.001 \\
\hline Nematode & Site & 3 & 64495 & 21498 & 0.001 & & & $\mathrm{CN}$ vs $\mathrm{CS}$ & 0.001 \\
\hline
\end{tabular}




\begin{tabular}{|c|c|c|c|c|c|c|c|c|c|}
\hline \multirow[t]{4}{*}{ composition } & Layer & 3 & 5725.7 & 1908.6 & ns & ES(51); SR & Site & $\mathrm{H}$ vs $\mathrm{G}$ & 0.005 \\
\hline & SxL & 9 & 15263 & 1695.9 & ns & & & $\mathrm{H}$ vs $\mathrm{CN}$ & 0.003 \\
\hline & Residual & 29 & 49023 & 1690.4 & & & & $\mathrm{H}$ vs CS & 0.001 \\
\hline & Total & 44 & 135440 & & & $\mathbf{J}$ & Site & $\mathrm{H}$ vs $\mathrm{G}$ & 0.001 \\
\hline \multirow[t]{3}{*}{ ES(51); SR } & Site & 3 & 758.17 & 39.535 & 0.001 & & & $\mathrm{H}$ vs CN & 0.001 \\
\hline & Res & 8 & 19.177 & & & & & $\mathrm{H}$ vs CS & 0.001 \\
\hline & Total & 11 & & & & & & CS vs $\mathrm{G}$ & 0.02 \\
\hline \multirow[t]{3}{*}{$\mathbf{J}$} & Site & 3 & 1025.2 & 163.61 & 0.001 & & & $\mathrm{CS}$ vs $\mathrm{CN}$ & 0.007 \\
\hline & Res & 8 & 6.2663 & & & ITD & Site & $\mathrm{H}$ vs $\mathrm{CS}$ & 0.005 \\
\hline & Total & 11 & & & & & & $\mathrm{CS}$ vs $\mathrm{G}$ & 0.014 \\
\hline \multirow[t]{3}{*}{ ITD } & Site & 3 & 357.23 & 14.045 & 0.002 & & & $\mathrm{CS}$ vs $\mathrm{CN}$ & 0.007 \\
\hline & Res & 8 & 25.435 & & & MI & Site & $\mathrm{H}$ vs $\mathrm{G}$ & 0.002 \\
\hline & Total & 11 & & & & & & $\mathrm{H}$ vs $\mathrm{CN}$ & 0.001 \\
\hline \multirow[t]{3}{*}{ MI } & Site & 3 & 36.44 & 47.043 & 0.001 & & & $\mathrm{H}$ vs CS & 0.03 \\
\hline & Res & 8 & 0.77461 & & & & & CS vs $\mathrm{G}$ & 0.003 \\
\hline & Total & 11 & & & & & & $\mathrm{CS}$ vs $\mathrm{CN}$ & 0.004 \\
\hline
\end{tabular}




\section{Table 2 (on next page)}

Indices of diversity at all sampling sites.

Nematode species richness (SR); the expected species number (ES[51]); Pielou index (J); the index of trophic diversity (ITD) and the maturity index (MI). All replicates are reported. 
2 Table 2:

3 Indices of diversity at all sampling sites. Nematode species richness (SR); the expected species number (ES[51]); Pielou index (J); the index of 4 trophic diversity (ITD) and the maturity index (MI). All replicates are reported.

\begin{tabular}{c|ccccccccccccc}
\hline & G1 & G2 & G3 & H1 & H2 & H3 & CN1 & CN2 & CN3 & CS1 & CS2 & CS3 \\
\hline SR & 51 & 63 & 61 & 12 & 11 & 7 & 69 & 72 & 45 & 52 & 74 & 55 \\
ES(51) & 22 & 24 & 22 & 4 & 6 & 3 & 27 & 25 & 23 & 20 & 24 & 19 \\
J & 0.80 & 0.80 & 0.77 & 0.29 & 0.28 & 0.34 & 0.85 & 0.81 & 0.86 & 0.73 & 0.71 & 0.67 \\
ITD & 0.63 & 0.59 & 0.45 & 0.63 & 0.76 & 0.63 & 0.49 & 0.58 & 0.52 & 0.40 & 0.33 & 0.34 \\
MI & 2.9 & 2.8 & 2.7 & 3.5 & 3.8 & 3.6 & 2.8 & 2.9 & 2.7 & 3.2 & 3.3 & 3.4 \\
\hline
\end{tabular}

5 


\section{Table 3(on next page)}

Results of DistLM procedure (Sequential test) for fitting sediment and interstitial water variables to the meiofauna and nematofauna variables.

$\%$ Var, percentage of explained variance; \% Cum, cumulative percentage explained by the added variable; ns, not significant. 
2 Table 3:

3 Results of DistLM procedure (Sequential test) for fitting sediment and interstitial water variables to the meiofauna and nematofauna variables.

$5 \%$ Var, percentage of explained variance; \% Cum, cumulative percentage explained by the added variable; ns, not significant.

\section{Meiofauna}

abundance

\begin{tabular}{lcccc} 
Variable & $\mathrm{R}^{\wedge} 2$ & $\mathrm{P}$ & $\mathrm{Var} \%$ & $\mathrm{Cum} \%$ \\
\hline $\mathrm{Cl}^{-}$ & 0.229 & $\mathrm{~ns}$ & 0.23 & 0.23
\end{tabular}

$$
\text { c }
$$

$\begin{array}{lllll}\mathrm{Zn} & 0.280 & \mathbf{n s} & 0.05 & 0.28\end{array}$

$\mathrm{T}\left({ }^{\circ} \mathrm{C}\right) \quad 0.654 \quad \mathbf{0 . 0 2} \quad 0.37 \quad 0.65$

$\begin{array}{lllll}\mathrm{pH} & 0.672 & \text { ns } & 0.02 & 0.67\end{array}$

$\begin{array}{llllll}\mathrm{Ca}^{2+} & 0.678 & \text { ns } & 0.01 & 0.68\end{array}$

$\begin{array}{lllll}\mathrm{Pb} & 0.820 & \text { ns } & 0.14 & 0.82\end{array}$

$\begin{array}{lllll}\text { Mud } & 0.928 & \text { ns } & 0.11 & 0.93\end{array}$

$\begin{array}{llllll}\mathrm{Cu} & 0.946 & \text { ns } & 0.02 & 0.95\end{array}$

$\begin{array}{lllll}\mathrm{Na} & 0.994 & \text { ns } & 0.05 & 0.99\end{array}$

$\underline{\mathrm{S}^{2-}}$

\section{Nematode biomass} \begin{tabular}{lcccc} 
Variable & $\mathrm{R}^{\wedge} 2$ & $\mathrm{P}$ & $\mathrm{Var} \%$ & $\mathrm{Cum} \%$ \\
\hline $\mathrm{K}^{+}$ & 0.630 & $\mathbf{0 . 0 0 1}$ & 0.630 & 0.630
\end{tabular}

$\begin{array}{llllll}\mathrm{Cu} & 0.699 & \text { ns } & 0.069 & 0.699\end{array}$

$\begin{array}{llllll}\mathrm{NO}_{3}{ }^{2-} & 0.731 & \text { ns } & 0.032 & 0.731\end{array}$

$\begin{array}{llllll}\text { Mud } & 0.742 & \text { ns } & 0.012 & 0.742\end{array}$

$\begin{array}{llllll}\mathrm{Zn} & 0.858 & \text { ns } & 0.116 & 0.858\end{array}$

$\begin{array}{llllll}\text { TOC } & 0.938 & \text { ns } & 0.080 & 0.938\end{array}$

$\begin{array}{lllll}\mathrm{pH} & 0.982 & \mathbf{0 . 0 1} & 0.044 & 0.982\end{array}$

$\begin{array}{llllll}\mathrm{Ca}^{2+} & 0.987 & \text { ns } & 0.005 & 0.987\end{array}$

$\begin{array}{llllll}\mathrm{Cl}^{-} & 0.991 & \text { ns } & 0.004 & 0.991\end{array}$
Meiofauna $n^{\circ}$ taxa

\begin{tabular}{lllll} 
Variable & $\mathrm{R}^{\wedge} 2$ & $\mathrm{P}$ & $\mathrm{Var} \%$ & $\mathrm{Cum} \%$ \\
\hline
\end{tabular}

$\begin{array}{llllll}\mathrm{Mg}^{2+} & 0.941 & \mathbf{0 . 0 1} & 0.093 & 0.941\end{array}$

$\begin{array}{llllll}\mathrm{pH} & 0.951 & \text { ns } & 0.010 & 0.951\end{array}$

$\begin{array}{llllll}\mathrm{Zn} & 0.961 & \text { ns } & 0.009 & 0.961\end{array}$

$\mathrm{T}\left({ }^{\circ} \mathrm{C}\right) \quad 0.964 \quad$ ns $\quad 0.003 \quad 0.964$

$\begin{array}{llllll}\mathrm{S}^{2-} & 0.971 & \text { ns } & 0.007 & 0.971\end{array}$

$\begin{array}{llllll}\text { TOC } & 0.979 & \text { ns } & 0.008 & 0.979\end{array}$

$\begin{array}{llllll}\mathrm{Ca}^{2+} & 0.985 & \text { ns } & 0.007 & 0.985\end{array}$

$\begin{array}{llllll}\mathrm{K}^{+} & 0.992 & \text { ns } & 0.007 & 0.992\end{array}$

\begin{tabular}{lllll}
$\mathrm{Pb}$ & 0.999 & ns & 0.007 & 0.999 \\
\hline
\end{tabular}

Nematode composition

\begin{tabular}{lcccc} 
Variable & $\mathrm{R}^{\wedge} 2$ & $\mathrm{P}$ & $\mathrm{Var} \%$ & $\mathrm{Cum} \%$ \\
\hline $\mathrm{NO}_{3}^{2-}$ & 0.521 & $\mathbf{0 . 0 0 1}$ & 0.521 & 0.521
\end{tabular}

$\begin{array}{lllll} & & & & \\ \mathrm{Na} & 0.633 & \mathbf{0 . 0 0 1} & 0.112 & 0.633\end{array}$

$\begin{array}{llllll}\mathrm{Ca}^{2+} & 0.709 & \mathbf{0 . 0 0 3} & 0.076 & 0.709\end{array}$

$\begin{array}{llllll}\text { TOC } & 0.757 & \text { ns } & 0.048 & 0.757\end{array}$

$\begin{array}{llllll}\mathrm{T} & \left({ }^{\circ} \mathrm{C}\right) & 0.798 & \text { ns } & 0.042 & 0.798\end{array}$

$\begin{array}{llllll}\mathrm{Pb} & 0.837 & \text { ns } & 0.039 & 0.837\end{array}$

$\begin{array}{llllll}\mathrm{Cu} & 0.872 & \text { ns } & 0.035 & 0.872\end{array}$

$\begin{array}{lllll}\mathrm{Mg}^{2+} & 0.906 & \text { ns } & 0.035 & 0.906\end{array}$

$\mathrm{Cl}^{-}$
Meiofauna taxonomic composition

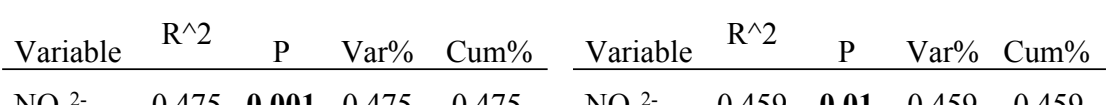

$\begin{array}{lllllllllll}\mathrm{T}\left({ }^{\circ} \mathrm{C}\right) & 0.582 & \mathbf{0 . 0 3} & 0.107 & 0.582 & \mathrm{~K}^{+} & 0.566 & \text { ns } & 0.107 & 0.566\end{array}$

$\begin{array}{lllllllllll}\mathrm{pH} & 0.664 & \mathbf{0 . 0 3} & 0.082 & 0.664 & \mathrm{~T}\left({ }^{\circ} \mathrm{C}\right) & 0.602 & \text { ns } & 0.036 & 0.602\end{array}$

$\begin{array}{lllllllllll}\mathrm{Cu} & 0.733 & \mathbf{0 . 0 3} & 0.069 & 0.733 & \mathrm{Na} & 0.716 & \text { ns } & 0.114 & 0.716\end{array}$

$\begin{array}{lllllllllll}\mathrm{K}^{+} & 0.785 & \text { ns } & 0.052 & 0.785 & \mathrm{Zn} & 0.732 & \text { ns } & 0.016 & 0.732\end{array}$

$\begin{array}{lllllllllll}\mathrm{Na} & 0.817 & \text { ns } & 0.031 & 0.817 & \mathrm{Ca}^{2+} & 0.801 & \text { ns } & 0.070 & 0.801\end{array}$

$\begin{array}{llllllllll}\mathrm{Zn} & 0.853 & \text { ns } & 0.036 & 0.853 & \text { TOC } & 0.901 & \text { ns } & 0.100 & 0.901\end{array}$

$\begin{array}{lllllllllll}\text { TOC } & 0.921 & \text { ns } & 0.068 & 0.921 & \mathrm{Cl}^{-} & 0.993 & \mathbf{0 . 0 0 4} & 0.092 & 0.993\end{array}$

$\begin{array}{llllllllllll}\mathrm{SO}_{4}{ }^{2-} & 0.964 & \text { ns } & 0.044 & 0.964 & \mathrm{Mg}^{2+} & 0.995 & \text { ns } & 0.002 & 0.995\end{array}$

\begin{tabular}{lllll}
$\mathrm{Ca}^{2+}$ & 0.985 & ns & 0.021 & 0.985 \\
\hline
\end{tabular}

Nematode diversity indices

\begin{tabular}{lllll}
$\mathrm{Cd}$ & 0.998 & ns & 0.003 & 0.998 \\
\hline
\end{tabular}

\begin{tabular}{|c|c|c|c|c|c|c|c|c|c|}
\hline \multicolumn{5}{|l|}{ 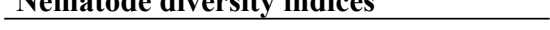 } & \\
\hline Variable & $\mathrm{R}^{\wedge} 2$ & $\mathrm{P}$ & $\operatorname{Var} \%$ & Cum $\%$ & Variable & $\mathrm{R}^{\wedge} 2$ & $\mathrm{P}$ & $\operatorname{Var} \%$ & Cum $\%$ \\
\hline $\mathrm{NO}_{3}{ }^{2-}$ & 0.888 & 0.01 & 0.888 & 0.888 & $\mathrm{Cl}^{-}$ & 0.627 & 0.01 & 0.627 & 0.627 \\
\hline $\mathrm{T}\left({ }^{\circ} \mathrm{C}\right)$ & 0.939 & 0.02 & 0.050 & 0.939 & TOC & 0.856 & 0.01 & 0.229 & 0.856 \\
\hline $\mathrm{S}^{2-}$ & 0.976 & 0.003 & 0.038 & 0.976 & $\mathrm{~T}\left({ }^{\circ} \mathrm{C}\right)$ & 0.882 & ns & 0.026 & 0.882 \\
\hline $\mathrm{Mg}^{2+}$ & 0.980 & ns & 0.004 & 0.980 & $\mathrm{Cu}$ & 0.920 & ns & 0.039 & 0.920 \\
\hline $\mathrm{Zn}$ & 0.983 & ns & 0.002 & 0.983 & $\mathrm{NO}_{3}{ }^{2-}$ & 0.964 & 0.03 & 0.043 & 0.964 \\
\hline $\mathrm{Na}$ & 0.985 & ns & 0.003 & 0.985 & $\mathrm{Cd}$ & 0.973 & ns & 0.010 & 0.973 \\
\hline $\mathrm{K}^{+}$ & 0.994 & 0.03 & 0.008 & 0.994 & $\mathrm{Na}$ & 0.985 & ns & 0.012 & 0.985 \\
\hline $\mathrm{Ca}^{2+}$ & 0.997 & ns & 0.003 & 0.997 & $\mathrm{Mg}^{2+}$ & 0.989 & ns & 0.004 & 0.989 \\
\hline $\mathrm{Cu}$ & 0.998 & ns & 0.001 & 0.998 & $\mathrm{~K}^{+}$ & 0.994 & ns & 0.005 & 0.994 \\
\hline
\end{tabular}


$\mathrm{Mg}^{2+}$ \begin{tabular}{llll}
0.998 & ns & 0.007 & 0.998 \\
\hline
\end{tabular}

\begin{tabular}{lllll}
$\mathrm{pH}$ & 0.977 & ns & 0.033 & 0.977 \\
\hline
\end{tabular}

$\underline{\mathrm{Pb}}$ 0.999

\begin{tabular}{llll}
0.997 & ns & 0.003 & 0.997 \\
\hline
\end{tabular} 7 